\title{
Firing the Wrong Workers: \\ Financing Constraints and Labor Misallocation
}

\author{
Andrea Caggese \\ Pompeu Fabra University, CREI, BGSE \\ Vicente Cuñat \\ London School of Economics \\ Daniel Metzger \\ Stockholm School of Economics*
}

October 2017

\begin{abstract}
Firms consider wages, current and expected productivity as well as firing and hiring costs when firing a worker. Financing constraints distort this intertemporal trade-off, leading firms to sub-optimally fire short-tenured workers with high future expected productivity. We provide empirical evidence of this distortion using matched employer-employee data from the Swedish population between 2000 and 2010. We propose a new empirical strategy that uses credit ratings to identify financing constraints and uses exchange rates and trade data to identify demand shocks. Our empirical results identify an important new misallocation effect of financial frictions that operates within firms across different types of workers.
\end{abstract}

JEL classification:

G32, J21, J24, J31

Keywords:

Labor misallocation, Firing decisions, Financing constraints

* Corresponding Author: Vicente Cuñat, v.cunat@lse.ac.uk, LSE, Department of Finance, Houghton Street, WC2A 2AE London, UK. Andrea Caggese: andrea.caggese@upf.edu, Daniel Metzger: daniel.metzger@hhs.se. We would like to thank Xavier Giroud, Harald Hau, Markus Schmid, Christoph Schneider, Toni Withed and an anonymous referee as well as seminar participants at the NBER Summer Institute 2016, the Labor and Finance Conference in Capri, AFA 2017, and 27th Mitsui Finance Symposium: Labor and Corporate Finance for their helpful comments and suggestions. We also thank Christoph Albert, Marta Alonso-Sanz and Virginia Minni, who provided excellent research assistance. The authors acknowledge the financial support of Resercaixa and AXA. 


\section{Introduction}

The effect of financing frictions on the investment decisions of firms is a longstanding question in economics. Asymmetric information, transaction costs or agency problems may limit the ability of firms to pledge future expected profits to raise funding, making them financially constrained and unable to finance profitable investment opportunities. The existing empirical literature has mostly focused on how the lack of financing can reduce the size of total physical investment (Hubbard, 1998). More generally, however, financing constraints distort any intertemporal decision that has cash flow implications by favoring projects that generate more cash or save costs in the short term (see, for example, Eisfeldt and Rampini, 2006). This type of trade-off is also relevant for many labor-related decisions that involve paying an upfront cost to improve the future expected productivity of the workforce, such as searching, screening, training, and firing.

The objective of the paper is to study how financing constraints affect the firing decisions of firms. In particular, we argue that financing constraints influence the types of workers who are fired across firms and have an important distortionary effect on the optimal allocation of employees, even when they have little effect on the total employment level. When deciding on which workers to fire, firms consider several factors, such as the current and future expected productivity and wages of a worker as well as firing and hiring costs. A firm may, for instance, be indifferent between firing a recently hired promising worker with low firing costs or a longer-tenured worker with low productivity growth but higher firing costs. Although all firms face similar trade-offs, financing constraints distort this decision, as constrained firms place more weight on current cash flows than on future ones. 
To illustrate these ideas and to guide our empirical analysis, we develop a stylized partial equilibrium model of a firm that makes hiring and firing decisions regarding heterogeneous workers. Financial frictions make credit-constrained firms discount future cash flows more severely than unconstrained firms. In the model, the productivity of workers varies during their tenures, so firms must keep replacing them to maximize productivity, even in the presence of firing costs. Moreover, recently hired workers have the potential to become more productive in the future, and therefore, their value for the firm includes an option component. Another key feature of the model is that wages are rigid and do not fully adjust to compensate for fluctuations in the productivity of workers. Finally, firing costs increase with workers' tenure in the firm.

In equilibrium, relative to normal times, a temporary negative demand shock makes it optimal for financially unconstrained firms to fire more long-tenured workers than shorttenured ones because the value of recent hires depends on future growth prospects and is less affected by temporary drops in their profitability. In this context, financial frictions affect not only the overall level of firm employment but also the optimal mix of shorttenured and long-tenured workers. More financially constrained firms have a higher opportunity cost of money and discount the option value of short-tenured workers more heavily, placing a larger weight on short-term returns. Moreover, long-tenured workers are less likely to be fired in constrained firms that have a higher opportunity cost of paying their firing costs. Finally, the higher firing hazard of short-tenured workers in constrained firms implies that a smaller fraction of them become long-tenured workers. As a consequence, the model implies the following four testable hypotheses. First, all else equal, the more financially constrained a firm is, the more likely it will be to fire a shorttenured worker, and the less likely it will be to fire a long-tenured worker. Second, the 
more financially constrained a firm, the shorter the tenure profile of its labor force. Third, in the event of a temporary exogenous shock that requires a reduction in employment, a financially unconstrained firm will fire more long-tenured workers than it would in normal times. Fourth, in the event of the same shock, a more financially constrained firm will fire relatively more short-tenured workers than a less constrained firm. These distortions operate through a labor demand channel and imply that financing constraints induce firms to fire workers with high productivity growth prospects, generating labor misallocation in equilibrium.

To understand the empirical relevance of the distortions, we analyze the effects of financing constraints on (i) the average firing policies of firms across tenures, (ii) the tenure profile of the labor force, (iii) the firing policies after an exogenous negative shock, and (iv) the types of workers fired. We test the predictions of the model using matched employer-employee data from the whole active population of Sweden over two decades: between 1990 and 2010. We match worker information with employer information, for which we have extensive balance sheet and credit score data. The exceptional quantity and quality of information available in this data set makes it ideal for our objective.

We measure financing constraints using well-established ratings of the population of Swedish firms. To match our empirical analysis with our theoretical setup, we focus on those firms with good ratings. Among these firms, different ratings imply heterogeneous access to credit and different interest rates. However, the firms in our sample are not financially distressed. We identify financing constraints in three different ways. First, we use three discrete rating categories, provided by the main rating company in Sweden, that measure the creditworthiness of firms. This specification captures the within-firm 
equilibrium correlations between firing and financing constraints. Second, we use a regression discontinuity design (RDD) that uses the thresholds (on a continuous risk measure) that determine credit ratings. Small differences in an underlying continuous default probability measure lead to discrete changes in a public rating that have important consequences for the perception of the creditworthiness of the firm. Our design exploits this discrete change in perceived creditworthiness by comparing firms that are arbitrarily close to a rating boundary but are on the different side of the threshold. Finally, the structure of the data allows us to compare long- and short-tenured workers within a firm in a given year. The specification absorbs any time-varying characteristics that affect both types of workers within a firm.

To identify exogenous changes in firing hazards, we use shocks to the exchange rate of a firm-specific basket of currencies. We construct this basket using the country composition of a firm's exports at the beginning of the sample period.

Our analysis concentrates on comparing the firing of short-tenured workers - who, on average, have steeper productivity profiles and lower firing costs - with that of longtenured workers. We first show that, on average, financially constrained firms employ more short-tenured workers than unconstrained firms. Second, after suffering an exchange rate appreciation shock, both constrained and unconstrained firms are more likely to fire workers. Importantly, however, we find significant differences in the types of workers fired across firms. On the one hand, the shock causes more firing of long-tenured workers in unconstrained firms, relative to normal times. The model predicts such behavior as a positive reallocation effect of temporary negative shocks, during which unconstrained firms fire the least efficient long-term workers and are more likely to keep short-term 
workers with more productivity growth potential. We perform additional robustness checks using a measure of expected productivity growth at the worker level that confirms this interpretation. On the other hand, constrained firms that suffer a negative shock fire more short-tenured than long-tenured workers, in comparison to financially unconstrained firms. Taken together, these results imply that financial frictions not only reduce the job stability of short-tenured workers but also generate an inefficient allocation of workers across firms and over time.

Quantitatively, we find that small exogenous changes in financing frictions generate potentially large distortions in the form of excessive firings of short-tenured workers. When we identify differences in financial frictions using the boundary between the two highest credit rating categories, we find that an increase in the cost of external financing of 0.15 percentage points implies that following an exogenous appreciation shock, the likelihood of being fired for short-tenured workers increases by approximately $10 \%$ relative to the average firing probability.

Finally, constructing empirical measures of the average productivity and expected productivity growth of workers, we provide direct evidence that these firing decisions of constrained firms are inefficient because they involve workers with relatively higher expected productivity growth than the workers fired by unconstrained firms.

Overall, the results are consistent with our analytical predictions and highlight an important - but relatively unexplored - form of misallocation: Financially constrained firms fire short-tenured workers with high skills and positive productivity growth prospects, who would be retained by less constrained firms. 
We believe that the results of the paper can be easily extrapolated to other labor market settings. In any dual labor market, with fixed-term and permanent workers, or in a labor market where severance payments increase with tenure, the studied effects are likely to be relevant and very strong. Moreover, even in the absence of regulatory frictions or severance pay, the interaction between financing constraints and worker productivity growing with tenure would generate the same results. Therefore, the main effects identified in the paper are generally applicable to most labor markets. Given that both financing constraints and labor frictions are, in relative terms, low in Sweden, one can interpret the results as a lower bound for the effect in other developed countries.

\section{Related Literature}

This paper is related to the recent empirical literature that studies the effects of financial frictions and financial shocks on the employment decisions of firms (see Pagano and Pica, 2012). Recent papers such as Chodorow-Reich (2014) for the U.S. and Bentolila, Jansen, Jiménez, and Ruano (2013) for Spain study the causal link from financial shocks to fluctuations in net employment levels, focusing on the quasi-natural experiment of the financial crisis. ${ }^{1}$ Our paper differs from these studies because it focuses on exogenous profitability shocks at the firm level rather than on aggregate financial shocks, and on their differential effect on constrained versus unconstrained firms. More importantly, it focuses on the effects on the type of workers fired and not the level of employment.

Our theoretical model and its predictions are based on the key insight that by increasing the opportunity cost of capital in the short term, financial frictions reduce the incentive to select projects with short-run costs and long-run gains that would be attractive

\footnotetext{
${ }^{1}$ See also Campello, Graham and Harvey (2010) and Almeida, Campello, Laranjeira and Weisbenner (2012).
} 
in the absence of financing constraints. Other authors that use the same insights are Eisfeldt and Rampini (2006), who study the effect of financial frictions on the trade-off between the decisions to buy new or used capital. Similarly, Caggese and Cuñat (2008) study the effects of financial frictions on the trade-off between hiring with fixed-term or permanent contracts. The latter can be a useful instrument to attract more productive workers but comes with larger expected termination costs. ${ }^{2}$

It is worth putting the paper in perspective with another stream of the literature that concentrates on the effects of financial distress on labor supply (e.g., Brown et al., 2016 and Baghai et al., 2016). In particular, Baghai et al. (2016) use similar data of Swedish workers to measure workers' voluntary departures in the three years prior to bankruptcy. In contrast, we measure the effects of financing constraints on labor demand and focus on relatively healthy firms to avoid capturing the influence of financial distress. ${ }^{3}$

\section{Analytical Framework}

In this section, we analyze a stylized model of a firm with heterogeneous workers and provide a set of testable predictions on the relation between financial frictions and firing decisions. The model focuses on the implications of the following three key features. First,

\footnotetext{
2 More generally, the theoretical model of this paper is related to the recent literature on financial frictions and the misallocation of resources across firms (see, for example, Buera, Kaboski and Shin, 2011; Caggese, and Cuñat, 2013; Midrigan and $\mathrm{Xu}, 2014$ ) and on the literature on financial frictions, the dynamics of hiring and firing, and employment fluctuations (among others, see Wasmer and Weil, 2004; Monacelli, Quadrini, and Trigari, 2011; Petrosky-Nadeau, 2014; Petrosky-Nadeau and Wasmer, 2015; Caggese and Perez, 2016).

${ }^{3}$ This contrasts with Baghai et al. (2016), who look at firms that have filed for bankruptcy. Instead, we focus on healthy firms with a credit rating between 1 and 3 (see Section 4.1. for details). The yearly propensity for initiating a bankruptcy process for firms with a rating between 1 and 3 is 0.68\% (compared with 7.09\% for lower rated firms). Applying our additional filters reduces this likelihood to $0.35 \%$ in our sample.
} 
wages are rigid and do not fully adjust to compensate for fluctuations in the productivity of workers. Second, recently hired workers have more upside potential than long-tenured workers. Third, firing costs increase with workers' tenure in the firm. For simplicity, the model considers the trade-off between firing short-tenured workers vs. long-tenured workers regardless of their age. However, the assumption that short-tenured workers have steeper productivity profiles than long-tenured ones implies that the model can also be interpreted as predicting how financing constraints affect the firings of younger versus older workers.

\subsection{The model}

Each worker produces an output equal to $\frac{A}{n_{t}^{1-\beta}} \mu$, where $A$ is firm-specific productivity, $\mu$ is worker specific productivity, $n_{t}$ is the number of workers, and $\beta \in(0,1)$ is a parameter capturing the elasticity of total firm output to total labor input $n_{t}$. A newly hired short-tenured worker has an initial productivity equal to $\mu^{Y}$, drawn from a uniform distribution $\left[\mu^{L}, \mu^{H}\right]$. Every short-tenured worker has a probability $\eta$ of becoming longtenured.

Conditional on becoming long-tenured, the worker draws a new productivity value, $\mu^{O}$, from a uniform distribution $\left[\mu^{L}, \phi \mu^{H}\right]$, where $\phi>1$ is the parameter that measures the ability of workers to become more productive as they accumulate more experience in the firm. This simple structure implies that while on average, workers become more productive with tenure, some of them may become less productive.

Firms can fire short-tenured workers without cost and long-tenured workers by paying a fixed firing cost, $F>0$, and they can hire new short-tenured workers by paying a fixed hiring cost, $v>0$. For simplicity, we assume that the productivity of new workers is 
observed only after the wage is decided and that the wage cannot be changed afterwards, and we derive the optimal decisions in the steady state, with constant interest rate $\mathrm{r}$ and firm-level productivity $A$. It follows that the optimal wage $w$ is constant both over time and across workers, and the optimal number of workers is also constant over time, i.e., $n_{t}=n$. Therefore, to simplify the analysis, we fix the wage $w$, and the associated division of surplus between firm and workers, at an arbitrary value that can be considered a reducedform representation of wage bargaining. At the end of this section, we relax this assumption and allow the wage to partly adjust to reflect fluctuations in worker productivity. Note that Sweden is one of the countries with the highest wage compression in the world, so the assumption that wages do not fully react to worker productivity is particularly relevant in our empirical setting. ${ }^{4}$

The timing of the interaction between the firm and the workers is as follows: at the beginning of each period, a worker exogenously leaves a firm with probability $\delta$, and the firm decides whether to fire workers who stay. Among continuing workers, a fraction $\eta$ of the short-tenured workers become long-tenured, while some new short-tenured workers are hired. Then, all workers produce and are paid a wage $w>0$.

\section{Value of long-tenured workers}

We define $V^{O}\left(\mu_{t}^{O}\right)$ as the value of a long-tenured worker who is employed in the firm until she quits, as a function of her productivity:

\footnotetext{
${ }^{4}$ In particular, wage compression guarantees that more productive workers are also more profitable for the firm. In countries where wages react more to individual worker productivity, the impact of worker productivity on firm profits should be smaller.
} 


$$
V^{O}\left(\mu_{t}^{O}\right)=\left(\frac{A}{n^{1-\beta}} \mu_{t}^{O}-w\right)+\frac{(1-\delta)}{1+r+\lambda} E_{t}\left[V^{O}\left(\mu_{t+1}^{O}\right)\right]
$$

where $r$ is the market interest rate, and $\lambda$ is a wedge that incorporates financial considerations; i.e., it is higher for more financially constrained firms. This wedge is a reduced-form measure of different types of financial frictions, such as higher opportunity costs of money caused by credit rationing, higher costs of borrowing, and higher bankruptcy probability. This definition of financial constraints can potentially identify both differences in restrictions to credit and interest rate differentials. Since our model and testable hypotheses are consistent with both types of frictions, we abstract from these considerations throughout the paper and consistently use the term financing constraints to refer to these rating differences. Since productivity is constant over time, $\mu_{t}^{O}=\mu^{O}$, it follows that

$$
V^{O}\left(\mu^{o}\right)=\left(\frac{A}{n^{1-\beta}} \mu^{O}-w\right) \frac{1+r+\lambda}{\delta+r+\lambda}
$$

A short-tenured worker with current productivity $\mu^{Y}$ who has not been fired in the current period has the following value:

$$
V^{Y}\left(\mu^{Y}\right)=\left(\frac{A}{n^{1-\beta}} \mu^{Y}-w\right)+\frac{(1-\delta)}{1+r+\lambda} \eta\left\{E\left[V^{O}\left(\mu^{O}\right)\right]\right\}+\frac{(1-\delta)}{1+r+\lambda}(1-\eta) V^{Y}\left(\mu^{Y}\right)
$$

which can be simplified as follows:

$$
V^{Y}\left(\mu^{Y}\right)=\frac{1+r+\lambda}{r+\lambda+\eta+\delta(1-\eta)}\left\{\left(\frac{A}{n^{1-\beta}} \mu^{Y}-w\right)+\frac{(1-\delta)}{1+r+\lambda} \eta\left\{E\left[V^{O}\left(\mu^{O}\right)\right]\right\}\right\}
$$

where the expected value conditional on becoming long-tenured, $E\left[V^{O}\left(\mu^{O}\right)\right]$, is equal to

$$
E\left[V^{O}\left(\mu^{O}\right)\right]=\left[\frac{A}{n^{1-\beta}}\left(\frac{1}{2} \phi \mu^{H}+\frac{1}{2} \mu_{\min }^{O}\right)-w\right] \frac{1+r+\lambda}{\delta+r+\lambda}
$$


where $\mu_{\min }^{O}$ is the minimum productivity of continuing long-tenured workers, and it will be determined in the next section.

\subsection{Employment-level decisions}

The optimal employment level $n$ is determined by the following free entry condition:

$$
E_{t}\left[V^{Y}\left(\mu^{Y}\right)\right]-v=0
$$

Since $V^{Y}\left(\mu^{Y}\right)$ is linear in $\mu^{Y}$, and workers are uniformly distributed across the values of $\mu^{Y}$, it follows that the expected value of a new short-tenured worker is

$$
E_{t}\left[V^{Y}\left(\mu^{Y}\right)\right]=\frac{1}{2} V^{Y}\left(\mu^{H}\right)+\frac{1}{2} V^{Y}\left(\mu_{\min }^{Y}\right)
$$

where $\mu_{\min }^{Y}$ is the minimum productivity of a short-tenured worker to avoid being fired.

Using equation Error! Reference source not found. to substitute $V^{Y}$ in Error! Reference source not found., it is possible to derive the optimal number of workers $n$, which is inversely related to financing frictions.

Proposition 1: $n$ is negatively related to $\lambda$.

A higher value of financing frictions $\lambda$ both increases the opportunity cost of hiring new workers, $v(1+r+\lambda)$, and reduces $V^{Y}$. For a formal proof, see Appendix 2 .

\subsection{Firing decisions in the steady state}

Given the free entry condition, short-tenured workers who have overly low productivity and have a negative value for the firm will be fired and replaced by a new worker such that the minimum productivity $\mu_{\min }^{Y}$ satisfies

$$
V^{Y}\left(\mu_{\min }^{Y}\right)=0
$$


and any short-tenured worker with productivity $\mu^{Y}<\mu_{\min }^{Y}$ is fired and replaced with a new worker. A firm will replace a long-tenured worker if her value is negative and larger in absolute value than firing costs such that the minimum productivity $\mu_{\min }^{O}$ satisfies

$$
V^{O}\left(\mu_{\min }^{o}\right)=-F
$$

The relation between $\mu_{\min }^{O}$ and $\mu_{\min }^{Y}$ is affected by two counteracting forces. On the one hand, the value of a short-tenured worker benefits from the option value of becoming very productive in the future. From equations Error! Reference source not found., Error! Reference source not found. and Error! Reference source not found., it immediately follows that $V^{Y}\left(\mu_{\min }^{O}\right)>V^{O}\left(\mu_{\min }^{O}\right)$. In other words, at the productivity level $\mu_{\min }^{O}$, a shorttenured worker is more valuable than a long-tenured one. The difference, $V^{Y}\left(\mu_{\min }^{O}\right)-$ $V^{o}\left(\mu_{\min }^{o}\right)$, increases with the value of the parameter $\phi$, which measures the growth opportunities of short-tenured workers. If this difference is larger than firing costs $F$, then $\mu_{\min }^{Y}<\mu_{\min }^{O}$, and the firm is more likely to fire a long-tenured than a short-tenured worker conditional on a given productivity level $\mu$, even though the long-tenured workers are costlier to fire.

On the other hand, a higher value of financing frictions $\lambda$ reduces the value of longtenured workers relative to the opportunity cost of firing, $F$, and reduces $\mu_{\text {min }}^{O}$, meaning that a more financially constrained firm will less frequently fire long-tenured workers. Moreover, it reduces the net present value of the future productivity of short-tenured workers, thereby reducing their option value and increasing $\mu_{\min }^{Y}$. Therefore, both effects imply that $\mu_{\min }^{Y}$ increases relative to $\mu_{\min }^{O}$. 
Proposition 2: A more financially constrained firm is likely to fire short-tenured workers more frequently than a less financially constrained firm with the same profitability, $A$, and the same quality of workers.

See Appendix 2 for a formal proof. Taken together, the above analysis shows that constrained firms are likely to fire short-tenured workers more frequently than unconstrained firms because financial frictions reduce the option value of these workers. Moreover, the higher firing hazard of short-tenured workers implies that a smaller fraction of them become long-tenured workers, thus increasing the share of short-tenured workers. Conversely, long-tenured workers become more difficult to fire, which increases the relative share of long-tenured workers. If firing costs are relatively low, as is the case of Sweden, the first effect is likely to prevail; therefore, we also predict that a more financially constrained firm will, in equilibrium, have a younger workforce.

\subsection{Firing decisions after a shock}

In this section, we assume that a temporary shock hits a firm at the beginning of a period, thereby reducing $A$. This reduced-form shock can be interpreted as any productivity or demand shock that reduces the revenues of the firm. For simplicity, we assume that this shock lasts only one period. The above equations imply that the value of workers decreases such that $\mu_{\min }^{Y}$ and $\mu_{\min }^{O}$ increase and the firm fires both some short-tenured and longtenured workers that period. Assuming that firing costs are relatively low and the growth prospects of young workers are relatively high, such that $\mu_{\min }^{Y}<\mu_{\min }^{O}$, it follows that the value of short-tenured workers for a firm relies heavily on their productivity growth potential rather than on their current productivity. Therefore, a temporary negative 
productivity shock affects them less than long-term workers, and $\mu_{\min }^{Y}$ increases relatively less than $\mu_{\min }^{O}$.

Proposition 3: Following a temporary drop in A, a financially unconstrained firm reduces employment by firing relatively more long-tenured workers than during normal times.

Proposition 3 implies that a temporary negative shock has a positive reallocation effect in which less productive workers—especially among those with longer tenures and fewer growth options-are fired across the tenure spectrum.

Furthermore, we can study the effect of financing frictions on the mix of short-tenured and long-tenured workers who are fired. From equation Error! Reference source not found., it follows that the more a firm is financially constrained, the more the value of its short-tenured workers is driven by current profitability $\left(\frac{A}{n^{1-\beta}} \mu^{Y}-w\right)$ rather than by the option value of becoming more productive in the future, $E\left[V^{O}\left(\mu^{O}\right)\right]$. Therefore, a temporary drop in A will have a much larger negative effect on the value of short-tenured workers for more financially constrained firms.

Proposition 4: Following a temporary drop in A, the more constrained a firm is, the more it fires short-tenured workers rather than long-tenured workers.

See Appendix 2 for a formal proof. It is important to note that financial frictions determine these predictions, as well as the steady-state predictions, by reducing the expected value of short-tenured workers (option value channel), increasing the opportunity cost of laying off more senior workers (firing cost channel), or both channels simultaneously. When firms are financially constrained, both channels increase the firing of short-term workers in both regular and shock times. Moreover, as long as firing costs 
are not too high, the option value channel is responsible for a higher equilibrium level of short-term workers in constrained firms and for the broader firing effect of financially unconstrained firms.

\subsection{Empirical predictions and empirical strategy}

The model described above implies the following testable predictions:

Hypothesis 1: The more financially constrained a firm is, the more likely it fires a shorttenured worker, and the less likely it fires a long-tenured worker.

Hypothesis 2: The more financially constrained a firm is, the younger the tenure profile of its labor force is.

Moreover, after an exogenous shock that requires a reduction in employment:

Hypothesis 3: A financially unconstrained firm reduces employment by firing relatively more long-tenured workers than it would during normal times.

Hypothesis 4: A more financially constrained firml fires workers with shorter tenures.

It is important to note that predictions 1,3 and 4 relate to firm-level decisions that are conditional on the intensity of the financial frictions the firms face. As such, we expect them to hold both when we compare firms with different intensities of financial frictions and when we examine a single firm over different periods of time. However, prediction 2 refers to the differential flows in and out of each tenure category as well as their long-run effects on the equilibrium tenure composition of the labor force. Therefore, we expect it to hold when we compare persistent differences in financial frictions across firms but not necessarily when we compare firms facing transitory shocks. 


\subsection{Firing and misallocation}

Hypotheses 1 and 4 imply that more financially constrained firms inefficiently fire workers with high growth prospects who would be retained by less financially constrained ones. However, it is plausible that with other frictions that are not included in the model, financing constraints could induce firms to make better employment decisions. It is therefore useful to directly test the misallocation effects in financially constrained firms. To empirically test this effect, we relax in the model the assumption of complete wage compression and assume that workers are paid a wage $\frac{A}{n^{1-\beta}} \gamma \mu+w>0$, where $0<\gamma<1$ indicates the sensitivity of wages to labor productivity, and $w$ is the fixed component. The

per-period profit that the firm receives from the worker becomes $\frac{A}{n^{1-\beta}}(1-\gamma) \mu-w$, but it does not otherwise affect the optimality conditions of the model or the four previous hypotheses. This assumption implies that more productive workers are paid more, but they are also more profitable for the firm. Importantly, assuming that $\gamma$ is greater than zero allows us to identify, in the empirical section, both different productivity levels across workers and their expected productivity growth using worker-level wage estimation models. Therefore, we are able to directly verify the misallocation consequences of the firing decisions of firms.

\section{Data and Descriptive Statistics}

This section describes the data set, and Section 5 describes the empirical strategy. A detailed list of all the variables used in the analysis and how they are constructed is reported in the External Appendix. 


\subsection{Firm data}

We test our hypotheses using matched employer-employee data of the universe of Swedish firms available for the 1998-2010 period from the Swedish Companies Registration Office (Bolagsverket), processed by the private data vendor PAR/Bisnode. The data include balance sheets and income statements of all Swedish limited liability companies (Aktiebolaget or AB).

We obtain rating information from $\mathrm{UC} \mathrm{AB}$, a rating agency owned by the largest four banks in Sweden. It provides yearly, automated credit reports on all enterprises registered in Sweden. Each report provides a discrete rating, commercially called a "credit score". Credit scores range from 1 (least constrained) to 5 (most constrained). These discrete ratings are based on a continuous measure, "Risk Forecast”, of the annual probability of default of the firm. Discrete thresholds of the continuous measure determine the 5 discrete ratings. ${ }^{5}$ The average (median) rating throughout the whole population of firms is 1.97 (2), suggesting that the firms in our sample are relatively unconstrained on average. The sample of credit ratings as well as its underlying continuous default probability are available for the 2001-2011 period.

International trade data are provided by Statistics Sweden and contain value information by trade type (import/export), product (8-digit classification), and country for each organization between 2000 and 2011. In terms of volume, the largest export markets are Germany (10.2\%), the USA (9.4\%), Norway (9.0\%), Great Britain (7.7\%), Denmark (6.0\%), and Finland (5.3\%). This diverse distribution of export markets is favorable for our

\footnotetext{
${ }^{5}$ In the original UC AB data, 1 corresponds to "most constrained" and 5 to "least constrained". We have reversed the order for our empirical analysis such that a higher number indicates higher financing constraints throughout the paper. The thresholds on the risk score are $0.245 \%, 0.745 \%, 3.045 \%$, and $8.045 \%$ and are determined by UC AB.
} 
purpose as they are located in different currency zones. We use these data to construct empirical measures of firm-specific exchange rate movements. We follow Park et al. (2010) and construct a weighted exchange rate, Shock Index, with respect to a basket of currencies to which companies are exposed. There is some independent variation across currencies, so different combinations of trading partners may imply that appreciations and depreciations of the firm-specific baskets coexist in a given year. Note that even though the export-based weights are kept constant throughout the sample, the Shock Index varies at a firm-year level.

To include a firm in our sample, we impose the following additional requirements: i) the firm employs at least 10 workers, ii) the firm appears for at least 5 consecutive years in our sample, and iii) the yearly workforce growth is restricted to be within $-50 \%$ and $+50 \%$.

Our final firm sample consists of 97,607 firm-year observations of 13,852 unique firms. On average, we have approximately 9,000 firms per year. The distribution of firmyears over our sample period of 11 years between 2001 and 2011 is relatively balanced over time with a minimum of $6.45 \%$ of all observations in 2001 and a maximum of $10.75 \%$ in 2007 . The average age of firms is approximately 13 years. The mean (median) employment is 102 (27) workers. The average annual growth rate of companies' labor force is $1.0 \%$. A fraction of $34 \%$ of the workforce has been with the firms for less than three years on average.

\subsection{Worker data}

Our basic sample is the "longitudinal integration database for health insurance and labor market studies” (LISA) provided by Statistics Sweden (SCB). The database holds annual registers since 1990 and includes all individuals 16 years of age and older who were 
registered in Sweden as of December 31 for each year. The data set contains employment information such as employment status, the identity of the employer, and wages.

Although our firm sample contains data only from 2001 onwards, we make full use of the whole sample period of LISA as it allows us to calculate the tenure of each worker more accurately and run our auxiliary wage regressions more efficiently. Applying the firm data requirements to the worker data results in a sample of approximately 6.9 million person-year observations. The average (median) worker is 39 (38) years old and male (66\%) and has been with the firm for 3.5 years on average. Approximately $6.2 \%$ of all workers are fired every year. We consider a worker as fired if i) she moves to a new firm / no firm in the next year and ii) claims unemployment benefits in the current or in the next year. The firing rates vary substantially by tenure. Approximately $10.3 \%$ of short-tenured workers (0-2 years with the firm) but only approximately $2.8 \%$ of long-tenured workers are fired every year.

\section{Empirical Strategy}

The main objective of the paper is to understand the firing policies of financially constrained and unconstrained companies in good and bad times across types of workers. In this section, we provide details about how we proxy for each of these measures as well as the specifications used in the paper. Jointly, they determine the identification strategy of the paper.

\subsection{Measuring financing constraints}

We use firm ratings as a measure of financing constraints. We focus on firms with credit scores ranging from 1 to 3 . This leaves out firms with ratings of 4 and 5 , which are 
potentially subject to financial distress. ${ }^{6}$ While distressed firms are clearly financially constrained, they also have characteristics that may make them undesirable for our analysis. In particular, they may have a very short time horizon in their investment decisions and strong incentives for risk-shifting through going concern. Therefore, their incentives to fire or restructure the workforce may be very different from those of regular firms outlined in our model.

Firm ratings directly measure the likelihood of default of a company; thus, they are a good proxy for the availability and cost of credit for a firm. It is therefore useful to run regressions that use ratings directly as a measure of financing constraints. Since they are determined simultaneously with firm productivity, investment opportunities and current policies, they must be interpreted as equilibrium relations between employment policies and financing constraints. Hence, our first set of regressions for each specification uses the first three discrete ratings of $\mathrm{UC} \mathrm{AB}$ as a measure of financing constraints, with and without including firm fixed effects.

However, it is also useful to run regressions in which we estimate the causal effect of an exogenous change in financing constraints. To do so, we use two further identification strategies: a regression discontinuity design (RDD) and a within-firm-year estimator.

The structure of our data (worker-year panel) allows us to make use of a within-firmyear estimator. We saturate the model with firm-year dummies and measure financing constraints using the discrete credit rating variable. This specification absorbs any common additive variation across worker types that is firm-year-specific. We therefore measure the

\footnotetext{
${ }^{6}$ While the yearly likelihood of initiating a bankruptcy process is $0.68 \%$ for firms with a credit rating between 1 and 3 , this likelihood increases to $7.09 \%$ for firms rated 4 or 5 .
} 
differential effect of financing constraints across different types of workers (long-tenured and short-tenured) for a given firm in a given year and compare this difference across different levels of financing constraints. This is an appealing specification, as many firm policies and characteristics are common to all types of workers.

In the RDD approach, we use the continuous risk forecast as the running variable of our analysis and the two boundaries between the first three ratings as the thresholds of our analysis. The RDD approach relies on two main assumptions. First, we assume that, asymptotically, the only source of heterogeneity is the running variable. That is, two firms with the same continuous risk forecast can be different, but asymptotically, they can be treated as being sampled from the same population of firms. Second, we assume that there is a discrete jump in the perception of financiers when a firm crosses a rating (credit score) threshold. In other words, ratings cause financing constraints in addition to being affected by financing constraints. We discuss the validity of these two assumptions in the following paragraph and present some evidence in Appendix 1. The first assumption implies, as a corollary, that the assignment to the running variable around a rating threshold is continuous and, in particular, that firms are not able to manipulate their risk forecast with precision near a credit score boundary. Several characteristics of the credit score support this assumption. First, the inter-annual variation in the running variable is quite large and it is hard for firms to predict with precision their continuous risk forecast. The within-firm standard deviation of the running variable (risk forecast) for the whole population of Swedish firms is $2.3 \%$, and the average inter-annual absolute change of the risk score is $1.7 \%$. This variation is quite large when compared with the thresholds that determine the discrete ratings, which are $0.25 \%$, and $0.75 \%$. Second, firms often change their credit rating from year to year. This implies that it is hard for firms to predict with enough 
precision their risk score in advance and to manipulate their risk score around the discontinuity (for details, see Tables A1 and A2 in Appendix 1). Finally, it is also worth noting that UC AB's rating is an absolute rating that adjusts to the business cycle to make the default probabilities valid at any given point in time (Jacobson and Lindé, 2000). This implies that even if a firm's balance sheet does not change much from one year to the next, its risk forecast and credit rating can still change.

In Figure A1, we show the density of firms around the discontinuity for the two boundaries analyzed. While the overall distribution of firms seems to reflect that firms are trying to belong to the higher categories, there does not seem to be evidence of manipulation on a narrow band around the discontinuity threshold.

The second assumption requires not only that the discrete "credit scores" reflect the financial health of the firm but also that exogenous changes in the "credit scores" cause changes in the availability and cost of credit for the firm. This is a reasonable assumption, as the discrete credit scores are observable to many agents, while the continuous risk forecast is available only to subscribers to the rating services. This is particularly relevant for the three first ratings, which are associated with three public certifications that firms can request and put physically in their businesses and electronically on their web pages. The three categories correspond to a gold badge for "highest creditworthiness", a silver badge for "high creditworthiness", and a bronze badge for "creditworthy". This form of public certification implies that these discrete categories may have important consequences for the availability of credit for firms. As a consequence, some financiers may also have rules that allow/preclude giving credit to firms depending on their credit score. The Central Bank of Sweden (Riksbank) explicitly reports that its risk assessments of aggregate default 
corporate risk are based on the discrete ratings provided by UC AB (Jacobson and Lindé, 2000).

Table A3 shows an additional specification check for both assumptions. We perform RDD regressions on contemporaneous and lead effects in which the dependent variables are leverage, the interest rate paid to financial institutions, and the total interest rate paid. The results in Panels B and C show that firms at the threshold are indistinguishable in terms of their characteristics in the previous years (thus supporting the first assumption). However, Panel A shows that they differ in their contemporaneous leverage and cost of debt variables (lending support to the second assumption). In particular, firms seem to have lower leverage once they become constrained (Columns 1 to 6) and higher bank interest rates (Columns 7-9). These estimated coefficients have all the expected signs and are statistically significant in some of the models, especially regarding the threshold between ratings 2 and 3. Overall, these results show that firms are ex-ante comparable at the rating threshold but that the threshold has some impact on their financial outcomes.

\subsection{Measuring firm shocks}

We construct empirical measures of negative shocks at the firm level that might induce firms to fire workers. We focus on firm-specific exchange rate shocks that hurt the export market of each firm. We use the weighted exchange rate Shock Index to construct an employment shock variable Shock (large), which captures observations within the $20 \%$ highest appreciation quantile within a year but also in the $50 \%$ highest appreciation quantile for the whole sample in all years. These employment shocks are determined by large appreciations of the Swedish Krona, with respect to the basket of representative currencies of a given firm. A sudden appreciation of the Krona makes the firm temporarily 
less competitive and may force the firm to lay off some workers and restructure production.

In our empirical analysis, we use Shock (large) as our preferred measure of exogenous shock because smaller shocks are likely to be absorbed on other margins (e.g., hours worked, inventories, prices, or domestic sales). Nonetheless, we use an alternative measure Shock (small) as a robustness check that captures observations within the $20 \%$ highest appreciation quantile within a year (see the External Appendix and Table EA3).

Table 1, Panel A shows that approximately $21 \%$ of firms are hit by an exchange rate shock by year. When we impose the additional condition that the shock must also be above the median across all years, this number declines to $13 \%$ on average.

\section{3. $\quad$ Measuring tenure and firing}

One of the assumptions of the model in Section 3 is that firing costs are higher for long-tenured workers. Swedish employment protection law indeed establishes that when firing workers because of "shortage of work", a firm must i) give a notice period of 1 month, which increases by one month every two years of tenure, up to a maximum of six months, and ii) fire according to a last-in-first-out (LIFO) rule within a given job role, which applies to all firms larger than ten employees. To retain a valuable newly hired worker, firms can circumvent the LIFO rule by using a narrow definition of the specific task to which the LIFO rule applies or by proposing a severance package to the protected workers or the unions (von Below and Thoursie, 2010). Firms can also fire workers outside the LIFO rule and pay an "unfair dismissal compensation”, which grows with tenure. For example, it is 16 months of salary for a worker with 5 years of tenure and 32 months for a worker with 10 years of tenure (Ius Labori, 2011). This outside option increases the 
bargaining power of workers as they accumulate tenure. Therefore, rather than being a constraint, the LIFO rule acts as a default policy from which it is feasible, but costly, to deviate. More specifically, the rule clearly tends to increase the costs of firing more senior workers, as does the tenure-specific notice period.

We measure the tenure (in years) of each worker in a given firm. We then create an indicator dummy Short-tenured that takes the value one if the worker has been working for the company for less than two full years. We choose a two-year definition to split between short-tenured and long-tenured contracts to match the duration of temporary contracts in Sweden. These can last for up to two years, so firing costs are convex at this threshold. Additionally, all Swedish employment contracts include a six-month trial period that entails a discrete jump in firing costs; however, given that we have only annual information, it is difficult to precisely define a tenure variable using this threshold. More generally, as explained above, the Swedish labor regulation entails that firing costs are monotonically growing and concave with respect to tenure. Skill acquisition within the firm is also likely to be convex and most pronounced in the first years of experience of workers. In Table EA6 in the External Appendix, we show that the results are qualitatively robust to using a tenure threshold of one or three years.

Unfortunately, there is no direct measure of firing in the data. The richness of the data, however, allows us to approximate firing quite precisely. We define a Fired dummy that is equal to one if a worker is becoming unemployed or if she changes jobs but receives unemployment benefits during the year of the transition. By imposing these restrictions, we aim to separate voluntary turnover from firing. Potentially, some of the fired workers in 
our sample leave voluntarily. ${ }^{7}$ This can add some noise to our estimations and attenuate our results. Depending on the correlation between voluntary leaves, firings and financing constraints, the voluntary leaves could also potentially bias our results. To explore this possibility, in a robustness check, we use more stringent definitions of firing, confirming all the results (see Table EA5). We also run regressions in which the dependent variable is voluntary leaves, defined as workers who switch from one firm to another without spending time unemployed. The results (reported in Table 4) are reversed for the main variables of interest in this alternative specification. These two sets of results indicate that if we have some voluntary leaves misclassified as firings, they are likely to bias our results downwards.

Panel B of Table 1 shows an average tenure of 3.5 years. Note that the date when a worker joins the firm is not recorded in the data, so we measure in-sample tenure; therefore, we cannot identify very long-tenure workers (those joining before 1990). However, given our definition of tenure (short vs. long-tenured) and the starting year of 2001 in our employment data, this data limitation is not a concern in our setting. The yearly turnover rate is between $16 \%$ and $18 \%$. When we restrict turnovers to cases that can clearly be identified as firings (see above), this rate declines to $6.2 \%$.

\subsection{Specifications}

\subsubsection{Firm-level regressions}

Consider the following firm-level specification:

\footnotetext{
${ }^{7}$ As a rule, workers in Sweden can access unemployment benefits if, during the previous year, they have worked at least six months and at least 80 hours per calendar month.
} 


$$
\mathrm{y}_{\mathrm{ft}}=\alpha+\theta \text { Shock }_{\mathrm{ft}-1}+\beta_{1}\left(\mathrm{C}_{\mathrm{ft}} * \text { Shock }_{\mathrm{ft}-1}\right)+\beta_{2} \mathrm{C}_{\mathrm{ft}}+\varepsilon_{\mathrm{ft}}
$$

In this specification, the dependent variable is the fraction of short-tenured workers employed at the firm or other outcome variables related to employment or firm characteristics, such as the average skill level of workers or their expected wage profile. Shock $_{\mathrm{ft}-1}$ is a firm-level appreciation shock lagged one period, and $\mathrm{C}_{\mathrm{ft}}$ is a measure of financing constraints based on the firm credit ratings. In most specifications, $\mathrm{C}_{\mathrm{ft}}$ takes value 1 if the firm belongs to rating 1 (gold badge), value 2 if the firm belongs to rating 2 (silver badge) and value 3 if the firm belongs to rating 3 (bronze badge).

\subsubsection{Worker-level regressions}

We also use worker-level data in which each observation is measured at worker (i), firm (f), and year (t) levels. The following is the worker-level regression with double interaction:

$$
y_{i f t}=\alpha+\theta \text { Shock }_{f t-1}+\beta_{1} C_{f t} \text { Shock }_{f t-1}+\beta_{2} C_{f t}+\varepsilon_{i t}
$$

where $y_{\text {ift }}$ is a proxy for a worker being fired that measures whether the worker involuntarily leaves the firm in the period between $t$ and $t+1$. We would like to estimate this relation for workers of long and short tenure inside the firm. To compare the coefficients across the different types of workers, we run a nested fully interacted version of the regression.

The fully interacted version of the regression is as follows:

$$
\begin{aligned}
& y_{i f t}=\alpha+\beta_{1} \text { Shock }_{f t-1}+\beta_{2} \text { Short_tenured }_{i t}+\beta_{3} C_{f t}+\beta_{4}\left(C_{j, f} * \text { Shock }_{f t-1}\right) \\
& +\beta_{5} \text { Short_tenured }_{i t} * \text { Shock }_{f t-1}+\beta_{6} C_{f t} \text { Short_tenured }_{i t} * \text { Shock }_{f t-1}+\varepsilon_{i t}
\end{aligned}
$$


where Short_tenured $d_{i t}$ is a dummy variable equal to one if the worker has two or fewer years of tenure. The estimation can be interpreted as a linear probability model of the likelihood of being fired. We pool all the years of each worker, so the results can be interpreted as a proportional hazard.

\subsubsection{Identification strategy}

We use three different sets of regression specifications for both firm-level and workerlevel analysis.

The first specification includes firm fixed effects and sector-year fixed effects; i.e., firm-level regression takes the following form:

$\mathrm{y}_{\mathrm{ft}}=\alpha+\delta_{f}+\gamma_{s t}+\beta_{1} \operatorname{Shock}_{\mathrm{ft}-1}+\beta_{2}\left(\mathrm{C}_{\mathrm{ft}} * \operatorname{Shock}_{\mathrm{ft}-1}\right)+\beta_{3} \mathrm{C}_{\mathrm{ft}}+\varepsilon_{\mathrm{ft}}$

where $\delta_{f}$ is a firm fixed effect, and $\gamma_{s t}$ is a sector-year fixed effect. Similarly, the workerlevel specification is equivalent to (13) with the same additional terms.

The effect in both specifications is identified within firm, net of any aggregate sector variation over time. Therefore, in this specification, any time-invariant characteristics of the firm or time-varying sector conditions that enter the firing decision in an additive way are absorbed.

The second specification takes advantage of the discrete nature of the credit ratings and estimates the effect of financing constraints at the boundaries of the discrete ratings. In the firm-level regressions, we include as additional control variables a polynomial of order 
12 on the continuous credit score variable $P$ (risk forecast). The firm-level specification therefore becomes ${ }^{8}$

$\mathrm{y}_{\mathrm{ft}}=\alpha+\delta_{f}+\gamma_{s t}+P($ risk forecast $)+\beta_{1}$ Shock $_{\mathrm{ft}-1}+\beta_{2}\left(\mathrm{C}_{\mathrm{ft}} * \operatorname{Shock}_{\mathrm{ft}-1}\right)+\beta_{3} \mathrm{C}_{\mathrm{ft}}+\varepsilon_{\mathrm{ft}}(14$

The polynomial $P$ (risk forecast) absorbs any continuous relation between financing constraints and the outcome variable, so $\beta_{2}$ and $\beta_{3}$ only capture discrete changes at the rating boundaries. The analogous specification at the worker level is

$y_{i f t}=\alpha+\delta_{f}+\gamma_{s t}+P($ risk forecast $)+\beta_{1}$ Shock $_{f t-1}+\beta_{2}$ Short_tenured $_{i t}+$

$\beta_{3} C_{f t}+\beta_{4}\left(C_{j, f} *\right.$ Shock $\left._{f t-1}\right)+\beta_{5}\left(\right.$ Short_tenured $_{i t} *$ Shock $\left._{s t-1}\right)+$

$\beta_{6} C_{f t}$ Short_tenured $_{i t} *$ Shock $_{f t-1}+\varepsilon_{i t}$

The effect in both specifications is therefore identified at the boundaries between two ratings. As discussed in Section 5.1, it is hard for firms to observe and manipulate their continuous credit rating with precision around a rating threshold. Hence, on a close boundary around the threshold, we can treat the assignment of a firm to each side of the threshold as random. Any potential confounding factors that are continuous at the threshold boundary (such as previous firing or hiring decisions) should therefore not participate in the identification.

The final specification is a within-firm-year specification in which we include firmyear fixed effects. The worker-level specification takes the following form:

\footnotetext{
${ }^{8}$ The order of the polynomial needs to be high enough to capture the continuous relation between the running variable (risk forecast) and any confounding factor that is continuous at the rating threshold. A polynomial of order 12 is sufficiently flexible, although the results are robust to using polynomials in and around this order.
} 


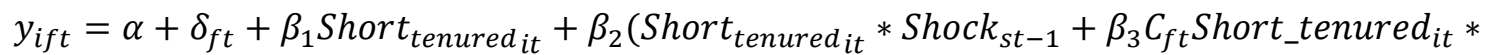

$\operatorname{Shock}_{f t-1}+\varepsilon_{i t}$

The firm-year fixed effects absorb any effects that are common to both types of workers within the firm, even if they are time varying. The estimates of this specification can therefore be interpreted as ceteris paribus of any additive time-varying effects that are common to both types of workers. Note that firm fixed effects, sector-year fixed effects, the constraints variable and the shock variable are all absorbed by the firm-year fixed effect. For this reason, the firm-level specification cannot be estimated with firm-year fixed effects. Note also that the second and third specifications are nested. However, the withinfirm estimator is also nesting an RDD specification in which even time-varying polynomials on the running variable are used to absorb the continuous effect of the risk forecast variable on both types of workers.

\section{Results}

\subsection{Firm-level regressions}

We start our analysis by showing firm-level regressions in which the dependent variable is the fraction of workers with tenure between 0 and 2 years inside the firm. The results in columns (1), (2), and (3) of Table 2 for the Shock variable are consistent across specifications and indicate that a negative export shock increases the fraction of shorttenured workers. The effect ranges between $1.4 \%$ and $0.8 \%$ across specifications. This is a relatively small effect considering that the fraction of workers with tenure under two years is $34 \%$. Next, the coefficient on the Constrained variable shows that financially constrained firms (i.e., firms with a worse rating by one grade) have on average between 
$1.5 \%$ and $4.3 \%$ more short-tenured workers. There is a consistent pattern across all six columns depending on the variation that identifies the coefficient. More specifically, the effect is quite large across firms (4.3\% per rating grade), but it is economically smaller once we introduce firm fixed effects (1.5\% per rating grade), and it becomes zero in the RDD specification. This suggests that the buffering of short-tenured workers is linked to permanent changes in the firm's financial health, but it is less pronounced when financing constraints are temporary. This is also the case in our model, in which the accumulation of short-term workers by constrained firms is an equilibrium steady-state phenomenon. Finally, the results for the interaction term Shock $X$ Rating show that constrained firms have fewer short-tenured workers when exposed to a negative export shock. The effect is between $-1.4 \%$ and $-0.8 \%$ per rating grade. Overall, the firm regressions suggest that in good times, constrained firms buffer short-tenured workers who are easier to fire in bad times. The results are consistent with the model, which predicts that in equilibrium, financially constrained firms employ more short-tenured workers on average (hypothesis 2), and conditional on firing workers, they fire relatively more short-tenured than longtenured workers, compared with less financially constrained firms (hypothesis 4). These results are also consistent with those of Caggese and Cuñat (2008), who focus on the type of employment contract used in equilibrium rather than on firing policies and tenure.

The main limitation of the firm results is that they simultaneously capture the effect of hiring, firing, separations, and workers accumulating tenure inside the firm. For this reason, in the next sets of regressions, we focus on worker-level regressions and specifically on firing. 


\subsection{Worker-level regressions}

In Table 3, we report worker-level regressions in which the dependent variable is a dummy variable that takes value 1 if a worker is fired within one year. The first set of specifications in columns (1) to (4) does not contain the shock variable or its interactions. The results are quite consistent across specifications. Short-tenured workers are more likely to be fired at any point in time as the estimated likelihood of being fired is 6 to 7 percentage points higher for them. These effects are also very large in relative terms given an unconditional probability of being fired of $6.2 \%$ across all workers. Constrained firms are less likely to fire long-tenured workers than unconstrained ones in the regression with firm fixed effects (column 2), while the RDD specification in Column (3) shows no significant effect. The final result of the first four columns is that short-tenured workers are more likely to be fired in constrained firms. The effect is large and significant and ranges between $0.7 \%$ and $0.9 \%$. Overall, these results are consistent with hypothesis 1 .

Columns (5) to (8) of Table 3 show the fully interacted specification including exchange rate appreciation shocks. The non-interacted coefficients follow the same pattern as in columns (1) to (4). The shock variable is associated with a positive and significant coefficient. Moreover, the interaction between shock and short tenure is negative and significant. In other words, when a shock hits unconstrained firms, they deviate from the LIFO policy and fire more long-tenured and fewer short-tenured workers relative to normal times, confirming Hypothesis 3. The overall effect on firing is relatively small (under 1\% compared with a baseline firing rate of 6\%). This is consistent with a temporary shock and the identification of over-deviations from an industry-year average. However, the composition of fired worker changes substantially in shock times for unconstrained firms. This broad firing effect of unconstrained firms may have long-term positive effects, as it 
allows unconstrained firms to fire the least productive workers across all tenure categories. This effect also explains the result of the firm regressions, showing that tenure decreases when firms are exposed to a shock. However, the next set of coefficients shows that this broad firing effect is not present in financially constrained firms.

The effect of the shock for the firing of long-tenured workers by financially constrained firms (the coefficient of Shock $X$ Rating) is negative and significant. This result is consistent with the model predictions that the costs of firing long-term workers are higher for financially constrained firms. Finally, the interaction between short-tenured, constrained and a negative shock has a clear positive coefficient across all specifications. Financially constrained firms fire an abnormally large fraction of short-tenured workers when they face a negative shock, confirming Hypothesis 4. The effect in columns (5) to (8) ranges between $0.6 \%$ and $0.8 \%$. This represents an increase of $10 \%-12.5 \%$ of the average firing probability. Taken together, the results show that in normal times, the firing rate of short-tenured workers is three times higher than that of long-tenured workers in unconstrained firms (gold badge) but five times higher in constrained firms (bronze badge). During shock times, the firing differential narrows down to a factor below two for unconstrained firms, but the convergence of firing rates is absent for constrained firms.

The magnitude of these effects appears even more striking once put in perspective with the size of the financing constraints captured by the rating. Given that we focus on relatively healthy firms, the differences in access to credit across ratings are small. For example, our estimates in Table A3 in Appendix 1 show increases with the average interest rates paid between $0.16 \%$ and $0.30 \%$. Alternatively, one can use, as benchmark, a riskneutral calculation in which lenders expect a return of $6 \%$, a recovery rate in case of 
default of 35\%, and the average default rates for each rating category. Such an exercise yields differences in the average interest rates of $0.24 \%$ across gold-silver ratings and 0.78\% across silver-bronze ratings. Junior loans could have a higher rate differential due to lower recovery rates, but in any case, the effect is bounded between $0.37 \%$ for the goldsilver transition and $1.21 \%$ for the silver-bronze transition when we assume zero recovery rates. ${ }^{9}$ Overall, the firms in our sample are financially healthy, although there are clear differences in the interest rates they pay that signify their different degrees of credit constraints.

\subsection{Robustness checks}

We run a number of robustness checks to confirm the results in the previous two sections. Unless otherwise specified, the results and the details of the robustness checks are shown in section EA2 of the External Appendix. We start with the definition of constrained and shock. We explore the individual rating boundaries (gold-silver and silverbronze) and focus on firms in which a downgrade is most surprising (those that were Gold for two years in a row before a downgrade). We also define the shock within a year using the Shock (small) variable definition. The results of these alternative specifications are consistent with the previous ones.

We then move on to the Firing variable. We consider two more stringent definitions of firing: the first one requires as additional condition at least 180 days of unemployment. The second one requires a drop in income of at least $10 \%$ when leaving the job. The results are stronger under these stricter definitions (see Table EA5). Moreover, in Table 4, we look at turnovers that are likely to be voluntary. We define voluntary as a turnover in which a worker switches across firms and does not claim unemployment benefits in

\footnotetext{
${ }^{9}$ See External Appendix 3 for related calculations.
} 
between. This variable (also used in Baghai et al., 2016) should capture mostly voluntary leaves and very few firings. When we use this definition of voluntary turnover instead of firings, the main results no longer hold. The specifications with firm fixed effects in Table 4 show that after a demand shock, in a financially unconstrained firm, short-tenured workers are actually more likely than long-tenured ones to voluntarily leave, thus reversing the positive reallocation effect found using the fired workers indicator. Moreover, the triple interaction coefficient is negative and significant instead of positive and significant. Overall, these results suggest that any misclassification of voluntary leavers as fired workers would actually dampen our results and is not driving them.

We also explore alternative tenure cuts to define short-tenured and long-tenured workers who use either a three-year threshold to define short-tenured or definitions that exclude workers of less than one year of tenure from the analysis. The results are, again, consistent with those in the previous two sections (see Table EA6).

The effect of exchange rate shocks is potentially heterogeneous across firms if firms are able to hedge their exposure through exchange rate derivatives. To rule out that this is a factor affecting our results, we also run regressions (Table EA7) in which we exclude firms with any financial assets (including derivatives). The results are robust to this exclusion. Note also that when firms hedge, they tend to hedge their profits directly and not their exports, so the marginal employment choices of hedged and non-hedged firms should be the same.

\section{Direct Evidence on Misallocation}

The previous section shows evidence of firing policies being distorted by the presence of financing constraints. In light of the model, these distortions imply labor misallocation 
because more financially constrained firms fire an inefficiently large share of workers with high productivity growth prospects. However, it is possible that other frictions not covered by the model make financially unconstrained firms make suboptimal decisions that could be attenuated by the presence of financing constraints. To rule out this possibility, in this section, we aim to provide direct evidence of this misallocation by focusing on the quality of workers who are fired and retained by constrained and unconstrained firms. We assess the quality of workers using measures of their permanent productivity and their future productivity. In particular, two productivity measures are calculated from separate wage regressions: a worker's predicted wage fixed effect and a worker's expected wage growth. We relate these measures to the firing policies of constrained and unconstrained firms distinguishing between when they are in normal times and when they are experiencing negative shocks.

\subsection{Skill composition of fired and retained short-tenured workers}

We explore the skill composition of short-tenured workers who are fired and retained. We estimate a wage regression that includes a third-order polynomial on workers’ potential work experience (age minus six minus years of education), year and firm fixed effects as well as a worker fixed effect. The worker fixed effect can be interpreted as an estimate of the worker’s time-invariant skills (see Abowd et al., 1999). We then run follow-up regressions (reported in Table 5) in which the dependent variable is the average skill level of short-tenure workers (average worker fixed effect) who are fired or retained in a given year. ${ }^{10}$ The regressions follow a similar structure as the two first columns of Table 2, and it

\footnotetext{
${ }^{10}$ The model has clear predictions about firms' policies for firing short-tenured workers. The model also has predictions with respect to long-tenured workers, but these depend on the assumptions made about the productivity transitions between short-tenured and long-tenured workers. For this reason, we focus on short-tenured workers only.
} 
is important to interpret both sets of results jointly, as the interpretation of the average skill level of fired and retained workers depends on the firing intensity of the firm.

Columns (1) and (2) show the skill profile of short-tenured workers who are fired. The first observed effect is that Shock is associated with a reduction in the skills of fired shortterm workers. The effect is sizeable, decreasing the average salary fixed effect of a fired worker by $2.7 \%$ to $3 \%$. The skill reduction is consistent with the results in Table 3; large negative shocks are used by firms to fire across the tenure spectrum. More long-tenured workers but fewer short-tenured workers are fired. The negative coefficient therefore reflects that when fewer short-tenured workers are fired, those fired have lower skills (i.e., are more selected). More generally, if we think of tenure as a continuum, given that the last-in-first-out pattern in firing is relaxed during negative shocks, we expect that the firms’ sorting of workers relies less on tenure and more on productivity. As the sorting of short-tenured workers according to their skill level becomes more pronounced, worse workers get fired. This broad firing effect suggests that temporary negative shocks can serve as a positive reallocation event in which unconstrained firms fire their less productive workers across the tenure spectrum.

Next, the coefficient on Constrained is also negative and significantly different from zero in the regression without firm fixed effects. This reflects the average skill-level effect of fired workers in constrained firms relative to unconstrained firms during normal times. Two counteracting effects are at work here. Constrained firms during normal times have firing policies that are closer to a last-in-first-out rule. This would predict a positive coefficient (more skilled short-term workers are fired). Simultaneously, as shown in Tables 2 and 3, constrained firms accumulate short-term workers during good times and fire more 
of them during periods with a negative trade shock. This second effect predicts a negative coefficient that dominates in the cross-sectional regression in Column (1).

Finally, the effect of Rating $X$ Shock in Table 5 is positive and significant. This shows that the effects of negative export shocks on unconstrained firms are lower for midconstrained firms (rating 2) or are non-existent for the most constrained firms in our sample (rating 3). This is evidence of a misallocation effect. When hit by negative shocks, constrained firms are forced to fire more skilled workers in order to reduce costs arising from severance pay or because more skilled workers are too costly to retain, given their intertemporal wage profiles.

Columns (3) and (4) of Table 5 display the analysis of stayers. In general, the coefficients of stayers comove with the coefficients of fired workers. The coherence of the coefficients on fired and stayers is consistent with firms firing workers who are less skilled than those whom they retain. It is also consistent with the missing category (workers who leave the firm voluntarily) not being highly correlated with the variables of interest. Note that if firms used a strict threshold strategy to fire their least able workers and there were no voluntary separations, the two coefficients would comove by construction. A positive coefficient indicates a higher firing threshold (the average worker fired is better) and a higher skill level of the retained worker. The interpretation of the results is similar to that of columns (1) and (2). For unconstrained firms exposed to a negative export shock, shorttenured stayers tend to have a lower skill level, which is consistent with more firings of longer-tenured workers and fewer firings of short-tenured ones. Constrained firms tend to hoard more short-tenured workers in good times; hence, their average skill level is lower. Note, however, that this effect is large in the cross section, with a $2 \%$ wage difference 
(column 3), but very small once we add fixed effects (0.3\% wage difference, Column (4). This is consistent with the results in columns (2) and (5) of Table 2, which show that the accumulation of short-tenured workers is largely a cross-sectional phenomenon, and it is less prominent when we focus on temporary shocks to financing constraints. Finally, the main result of interest is that the interaction between negative export shocks and constraints is positive. As observed in Tables 2 and 3, constrained firms fire more shorttenured workers when exposed to a negative shock, and the average quality of the workers who stay is higher for these firms, precisely because they are letting some of their good workers go. The size of the coefficient is similar to the one for unconstrained firms. This means that the broad firing effect that shocks have on unconstrained firms cancels out for mid-constrained firms (rating 2), while for firms with high constraints (rating 3), the effect is reversed.

Taken jointly with the results in the previous section, the results in Table 5 show, first, that the skill profile of workers who are fired or stay in the firm is generally consistent with the use of a rule that resembles a threshold strategy within a tenure category. Second, unconstrained firms have a broad firing policy after negative shocks, when they fire across all tenures and retain more skilled workers. Finally, constrained firms deviate less from the LIFO policy; they fire more short-tenured workers following a negative shock, and these workers have higher skill levels.

\subsection{Expected productivity growth and firing of workers}

In Table 6, we explore the expected wage profiles of fired workers in constrained and unconstrained firms. As shown in the model, retaining workers with a steep intertemporal productivity profile is akin to an investment decision. Firms must maintain a currently 
unproductive short-tenured worker as they wait for a future expected productivity increase. Wage compression plays a dual role in this prediction: first, wages smooth the intertemporal changes in worker productivity, so workers with low productivity are overpaid with respect to their productivity, and workers with high productivity are relatively under-paid. Second, wages underreact to differences in worker productivity, so they are a good proxy of the profit that firms extract from a given worker (i.e., on average, a higher paid worker overcompensates for the higher wage with even higher productivity levels).

To approach this question, we first run a regression of the three-year future wage growth of a worker as a function of a potential experience (age minus six minus years of education), demographic information and family composition (gender, number of children and marital status), as well as very detailed educational achievements (grades and program in high school and highest level of education). The model is similar to the model in Boehm, Metzger, and Stromberg (2016), who estimate predicted cognitive skills for the whole Swedish population. We estimate the model running a regression that uses unconstrained firms only (rating=1) to avoid a scenario in which the distortions associated with financing constraints introduce any biases. We then predict the wage growth for all workers in the sample and create a dummy variable (High wage growth) that takes value 1 if the worker is predicted to have a wage growth above the median wage growth of the whole population. We include an RDD specification without fixed effects and the same specifications as in columns 3 and 4 of Table 3 (RDD with fixed effects and firm-year fixed effects).

Columns (1) to (3) of Table 6 include only short-tenured workers, and columns (4) to (6) include only long-tenured workers. The results show, in the first row, that workers with 
low productivity today (relative to their future productivity) tend to be fired more often. This effect is stronger for short-tenured workers: if retaining some workers (e.g., shorttenured workers) is akin to an investment decision, it is likely that these workers get fired more often than those who already have a high realized productivity. This effect is emphasized for constrained firms, as shown by the coefficients on Rating X High wage growth. Given that retaining these workers is a form of investment, constrained firms fire them more often. The effect is substantial, as the likelihood of being fired is approximately 10\% higher per rating (i.e., 20\% higher when going from gold to bronze ratings).

The second row shows that when firms experience productivity shocks, this effect is attenuated, and fewer workers with high expected future wage growth are fired. Moreover, the coefficient of Shock is positive (in the regressions with firm fixed effects), indicating that more workers with low future expected wage growth are fired. This is consistent with the results of Table 3 and Table 5 . Negative shocks are used by firms to fire more longtenured workers, workers with higher firing costs and workers with low future expected productivity growth. However, this effect is significantly attenuated for constrained firms. The positive coefficient of the triple interaction High wage growth X Shock (large) X Rating indicates that constrained firms facing a shock fire their most promising workers, in contrast with the firing policy of unconstrained firms. These results are consistent throughout the three specifications.

The results are also consistent for both short-tenured and long-tenured workers. However, they are larger for short-tenured workers. This is consistent with steeper wage profiles, and higher option values (as defined in the model), among short-tenured workers. It is also consistent with firing costs being higher for long-tenured workers, making 
productivity profiles less relevant. In the previous sections, we proxied wage profiles (jointly with firing costs) directly using tenure. In this section, we have direct measures of expected wage growth, but tenure is still likely to capture workers who are cheaper to fire and have higher average productivity growth rates.

Overall, the results of this section provide independent and direct evidence of distortions in the firing process associated with financing constraints. These distortions in firing policies have real consequences as they lead to a workforce with lower productivity in constrained firms.

\section{Conclusions}

The paper studies the effects of financing constraints on the firing decisions of firms. As firing is an intertemporal decision that can be interpreted as a particular form of investment. It is reasonable to assume that firing decisions will be affected by the presence of financing constraints as well.

We illustrate the main forces at play in a partial equilibrium dynamic stochastic model of a firm, which may be subject to financial frictions and makes the hiring and firing decisions regarding workers who are heterogeneous in their productivity paths and firing costs. The model predicts that financing constraints affect the types of workers who are fired within and across firms and have potentially important distortionary effects on the optimal allocation of employees, even if they have little effect on the total employment level.

We estimate firing decisions at the firm and worker levels using a rich data set of matched employer-employee data from the whole active population of Sweden between 
1990 and 2010. The results show that financially constrained firms i) accumulate more short-tenured workers as a fraction of their labor force than unconstrained firms. ii) They tend to fire more short-tenured workers. iii) The effect in ii) is more pronounced when financially constrained firms experience negative shocks. In contrast, financially unconstrained firms have generally a less pronounced LIFO firing policy, and this is particularly the case after experiencing negative shocks. Relatedly, our results regarding the average skills and wage profiles of fired workers show that unconstrained firms are more efficient in retaining good and promising workers and that they use periods of negative shocks to fire the least productive workers across all tenures. These creative destruction effects of negative shocks are absent or even reversed for constrained firms.

Long-tenured workers are relatively more protected against firm shocks in financially constrained firms, as financing constraints tend to emphasize an LIFO firing policy. The additional firing of short-tenured workers by financially constrained firms after a shock accounts for an increase of approximately $7 \%$ relative to the baseline firing probability of a short-tenured worker. This is a sizeable effect, especially considering that we focus on relatively healthy firms and that dropping one rating in our sample accounts for an increase of up to $0.3 \%$ in marginal interest rates.

These results uncover a novel empirical fact: financial frictions distort firm firing decisions towards inefficient firing of short-tenured workers. Financing constraints increase labor duality within firms with highly protected long-tenured workers and more exposed short-tenured workers, with potentially important negative consequences for the misallocation of resources across firms, the process of human capital accumulation and the career paths of young workers. More generally, we highlight the interaction between 
financial frictions and labor market frictions and the need to study them jointly. It is likely that the effects that we show using Swedish data are larger in countries with higher labor market duality (e.g., coexistence of temporary and permanent contracts with very heterogeneous firing costs) and in countries where firms face poorer access to financial markets. 


\section{References}

Abowd, J.M., Kramarz, F., Margolis, D.N., 1999. High wage workers and high wage firms. Econometrica 67, 251-333.

Almeida, H., Campello, M., Laranjeira, B., Weisbenner, S., 2012. Corporate debt maturity and the real effects of the 2007 credit crisis. Critical Finance Review 1, 3-58.

Baghai, R., Silva, R., Thell, V., Vig, V., 2016. Talent in distressed firms: Investigating the labor costs of financial distress. Unpublished working paper. Stockholm School of Economics.

Bentolila, S., Jansen, M., Jiménez, G., Ruano, S., 2017. When credit dries up: Job losses in the Great Recession. Journal of the European Economic Association, jvx021.

Bertrand, M., 2004. From the invisible handshake to the invisible hand? How import competition changes the employment relationship. Journal of Labor Economics 22, 723766.

Böhm, M. J., Metzger, D., Strömberg, P., 2015. 'Since you're so rich, you must be really smart': Talent and the finance wage premium. Unpublished working paper. Riksbank.

Brown, J., Matsa, D.A., 2016. Boarding a sinking ship? An investigation of job applications to distressed firms. Journal of Finance 71, 507-550.

Buera, F. J., Kaboski, J.P., Shin, Y., 2011. Finance and development: A tale of two sectors. American Economic Review 101, 1964-2002.

Caggese, A., Cuñat, V., 2008. Financing constraints and fixed-term employment contracts. Economic Journal 118, 2013-2046. 
Caggese, A., Cuñat, V., 2013. Financing constraints, firm dynamics, export decisions, and aggregate productivity. Review of Economic Dynamics 16, 177-193.

Caggese, A., Perez, A., 2016. The interaction between household and firm dynamics and the amplification of financial shocks. Unpublished working paper. Barcelona GSE.

Campello, M., Graham, J., Harvey, C.R., 2010. The real effects of financial constraints: Evidence from a financial crisis. Journal of Financial Economics 97, 470-487.

Chodorow-Reich, G., 2014. The employment effects of credit market disruptions: Firmlevel evidence from the 2008-9 financial crisis. The Quarterly Journal of Economics 129, $1-59$.

Cuñat, V., Guadalupe, M., 2009. Globalization and the provision of incentives inside the firm. The Journal of Labor Economics 27, 179-212.

Eisfeldt, A.L., Rampini, A., 2007. New or used? Investment with credit constraints. Journal of Monetary Economics 54, 2656-2681.

Hubbard, G.R., 1998. Capital-market imperfections and investment. Journal of Economic Literature 36, 193-225.

Ius Labori, 2011. Individual dismissals across Europe. $2^{\text {nd }}$ Edition. Global Human Resources Lawyers, Brussels.

Jacobson, T., Lindé, J., 2000. Credit rating and the business cycle: Can bankruptcies be forecast? Sveriges Riksbank Economic Review 4, 11-33..

Midrigan, V., Xu, D.Y., 2014. Finance and misallocation: Evidence from plant-level data. American Economic Review 104, 422-58. 
Monacelli, T., Quadrini, V., Trigari, A., 2011. Financial markets and unemployment. Unpublished working paper. National Bureau of Economic Research.

Pagano M., Pica, G., 2012. Finance and Employment. Economic Policy 69, 5-55.

Park, A., Yang, D., Shi, X., Jiang, Y., 2010. Exporting and firm performance: Chinese exporters and the Asian financial crisis. Review of Economics and Statistics 92, 822-842.

Petrosky-Nadeau, N., 2014. Credit, vacancies and unemployment fluctuations, Review of Economic Dynamics 17, 191-205.

Petrosky-Nadeau, N., Wasmer, E., 2015. Macroeconomic dynamics in a model of goods, labor and credit market frictions. Journal of Monetary Economics 72, 97-113.

Revenga, A.L., 1992. Exporting jobs? The impact of import competition on employment and wages in U.S. manufacturing. Quarterly Journal of Economics 107, 255-284.

Thorburn, K.S., 2000. Bankruptcy auctions: Costs, debt recovery and firm survival. Journal of Financial Economics 58, 337-368.

Von Below, D., Thoursie, P.S., 2010. Last in, first out?: Estimating the effect of seniority rules in Sweden. Labour Economics 17, 987-997.

Wasmer, E., Weil, P., 2004. The Macroeconomics of labor and credit market Imperfections. American Economic Review 94, 944-63. 


\section{Tables}

\section{Table 1: Summary Statistics}

This table shows summary statistics for firms (Panel A) and workers (Panel B). The sample period is 2001 2010. Shock is an exchange rate shock. In "Shock (small)" the exchange rate shock is equal to one for the $20 \%$ highest appreciation quantile within a year, and zero otherwise. Otherwise, we denote with "Shock (large)" the regressions in which we qualify as shocks larger appreciations, within the $20 \%$ highest appreciation quantile within a year, but also in the $50 \%$ highest appreciation quantile for the whole sample. Constrained is a categorical variable equal to $1 \ldots .3$ (1=best rating, $3=$ worst rating). Constrained 1 vs. 2 is a dummy that takes the value of one if the rating is 2 . It is defined for firms with a rating of 1 or 2 . Constrained 2 vs. 3 is a dummy that takes the value of one if the rating is 3. It is defined for firms with a rating of 2 or 3. Assets $(\log )$ measures the logarithm of total assets at the end of the calendar year. Firm age is the age of the firm in years (the variable is calculated from worker data (LISA) and, hence, truncated at year 1990). In our regression specifications we create categorical variables for firm age to deal with this issue. Workforce denotes the number of workers that are working in a firm (calculated from LISA). Workforce growth is the growth of the workforce between year $t$ and $t+1$ in percent. Tenure $0-2$ years $\mid$ fired is the fraction of fired workers with tenure of 0-2 years among all fired workers. Tenure 0-2 years denotes the Fraction of workers with tenure 0-2 years. Sources: SCB LISA, UC AB, Bolagsverket.

\section{Panel A: Firm Characteristics}

Assets (log)

Firm age

Workforce

Workforce growth

Tenure 0 -2 years | fired

Fraction of workers with tenure $0-2$ years

FX Shock (small)

FX Shock (large)

Constrained

Constrained 1 vs. 2

Constrained 2 vs. 3

\begin{tabular}{ccccc} 
mean & $\mathbf{p 2 5}$ & $\mathbf{p 5 0}$ & $\mathbf{p 7 5}$ & $\mathbf{N}$ \\
\hline 17.339 & 16.351 & 17.096 & 18.060 & 97597 \\
13.217 & 10.000 & 14.000 & 17.000 & 97607 \\
101.822 & 16.000 & 27.000 & 61.000 & 97607 \\
0.010 & -0.071 & 0.000 & 0.089 & 97607 \\
0.676 & 0.500 & 0.792 & 1.000 & 60958 \\
0.339 & 0.190 & 0.308 & 0.452 & 97607 \\
& & & & \\
0.213 & 0.000 & 0.000 & 0.000 & 97607 \\
0.131 & 0.000 & 0.000 & 0.000 & 97607 \\
1.899 & 1.000 & 2.000 & 3.000 & 97607 \\
0.403 & 0.000 & 0.000 & 1.000 & 67277 \\
0.528 & 0.000 & 1.000 & 1.000 & 57457
\end{tabular}


Panel B shows summary statistics for workers. The sample period is 1999 - 2010. Fired is a dummy variable that is equal to one if a worker is fired in a given year. We consider a worker as fired if $\mathrm{i}$ ) she moves to a new firm / no firm in the next year and ii) claims unemployment benefits in the current or in the next year. Tenure denotes the number of years a worker is with a given firm. Fired conditional on short and long tenure is based on short tenure ( $0-2$ years) and long tenure ( 3 and more years). Age is the age of the worker in years. Female is a variable that takes the value of 0 for men and 1 for women. Sources: SCB LISA.

Panel B: Worker Characteristics

\begin{tabular}{lccccc} 
& mean & $\mathbf{p 2 5}$ & $\mathbf{p 5 0}$ & $\mathbf{p 7 5}$ & $\mathbf{N}$ \\
\cline { 2 - 6 } Age & 38.998 & 29.000 & 38.000 & 48.000 & $6,893,496$ \\
Female & 0.335 & 0.000 & 0.000 & 1.000 & $6,893,496$ \\
Tenure & 3.534 & 1.000 & 3.000 & 6.000 & $6,893,496$ \\
Fired & 0.062 & 0.000 & 0.000 & 0.000 & $6,893,496$ \\
Fired | Short-tenure & 0.103 & 0.000 & 0.000 & 0.000 & $3,145,526$ \\
Fired | Long-tenure & 0.028 & 0.000 & 0.000 & 0.000 & $3,747,970$
\end{tabular}




\section{Table 2: Financing Constraints and Workers Tenure}

The dependent variable is the fraction of young tenured workers (0-2 years with the firm). Constrained is a categorical variable equal to 1,2,3 (1=best rating, $3=$ worst rating). Shock is an exchange rate shock. "Shock (large)" is equal to one for the $20 \%$ highest appreciation quantile within a year but also in the $50 \%$ highest appreciation quantile for the whole sample, and zero otherwise. Specifications (1) and (4) are simple OLS regressions with industry-year dummies. Specifications (2)-(3) and (5)-(6) include firm fixed effects. Specifications (3) and (6) use a regression discontinuity design (RDD) with polynomials. Polynomial indicates a polynomial of order 12 of the running variable "risk forecast". Sources: SCB LISA, UC AB, Bolagsverket. *** p $<0.01$ ** $p<0.05 * \mathrm{p}<0.1$.

Shock (large)

Constrained

Shock (large) X Constrained

\begin{tabular}{c}
$(1)$ \\
\hline $0.014^{* *}$ \\
$(0.005)$ \\
$0.043^{*}$
\end{tabular}

(2)

Fraction of workers with tenure $0-2$ years

\section{Observations}

Polynomial on Credit Risk

Industry-Year fixed effects

Firm fixed effects

\begin{tabular}{cccccc}
$0.043^{* * *}$ & $0.015^{* * *}$ & -0.003 & $0.042 * * *$ & $0.014 * * *$ & -0.004 \\
$(0.001)$ & $(0.001)$ & $(0.003)$ & $(0.001)$ & $(0.001)$ & $(0.003)$ \\
$-0.014 * * *$ & $-0.008^{* * *}$ & $-0.008 * * *$ & & & \\
$(0.002)$ & $(0.002)$ & $(0.002)$ & & & \\
\hline 97077 & 97077 & 97077 & 97077 & 97077 & 97077 \\
No & No & Yes & No & No & Yes \\
Yes & Yes & Yes & Yes & Yes & Yes \\
No & Yes & Yes & No & Yes & Yes
\end{tabular}


Table 3: Financing Constraints and Firing

This table estimates regressions at the worker level. The dependent variable is binary variable equal to one if the worker leaves the firm in period $t$ and receives unemployment benefits afterwards, and zero otherwise. Shock (large) is an exchange rate shock. "Large" refers to shocks of larger appreciations, within the $20 \%$ highest appreciation quantile within a year, but also in the $50 \%$ highest appreciation quantile for the whole sample. Constrained is a categorical variable equal to 1,2,3 (1=best rating, 3=worst rating). Short-tenured is a dummy equal to one for workers with 0 to 2 years of tenure, and zero otherwise. Polynomial indicates a polynomial of order 12 of the running variable "risk forecast". Sources: SCB LISA, UC AB, Bolagsverket. *** $\mathrm{p}<0.01 * * \mathrm{p}<0.05 * \mathrm{p}<0.1$.

Short-tenure

Shock (large)

Short-tenure X Shock (large)

Constrained

Short-tenure X Constrained

Shock (large) $=1 \mathrm{X}$ Constrained

Short-tenure X Shock (large)=1 X Constrained

Observation

Polynomials

Industry-Year fixed effects

Firm fixed effects

\begin{tabular}{cccccccc}
\multicolumn{7}{c}{ Fired Next Year } \\
$(1)$ & $(2)$ & $(3)$ & $(4)$ & $(5)$ & $(6)$ & $(7)$ & $(8)$ \\
\hline $0.058^{* * *}$ & $0.060^{* * *}$ & $0.060^{* * *}$ & $0.066^{* * *}$ & $0.064^{* * *}$ & $0.064^{* * *}$ & $0.064^{* * *}$ & $0.070^{* * *}$ \\
$(0.000)$ & $(0.000)$ & $(0.000)$ & $(0.000)$ & $(0.000)$ & $(0.000)$ & $(0.000)$ & $(0.001)$ \\
- & - & - & - & $0.002^{* * *}$ & $0.009^{* * *}$ & $0.009^{* * *}$ & - \\
- & - & - & - & $(0.001)$ & $(0.001)$ & $(0.001)$ & - \\
- & - & - & - & $-0.033^{* * *}$ & $-0.024^{* * *}$ & $-0.024^{* * *}$ & $-0.024^{* * *}$ \\
- & - & - & - & $(0.001)$ & $(0.001)$ & $(0.001)$ & $(0.001)$ \\
$0.007^{* * *}$ & $-0.003^{* * *}$ & -0.000 & - & $0.007^{* * *}$ & $-0.002^{* * *}$ & -0.000 & - \\
$(0.000)$ & $(0.000)$ & $(0.001)$ & - & $(0.000)$ & $(0.000)$ & $(0.001)$ & - \\
$0.009^{* * *}$ & $0.007^{* * *}$ & $0.007^{* * *}$ & $0.007^{* * *}$ & $0.007 * * *$ & $0.006 * * *$ & $0.006^{* * *}$ & $0.006^{* * *}$ \\
$(0.000)$ & $(0.000)$ & $(0.000)$ & $(0.000)$ & $(0.000)$ & $(0.000)$ & $(0.000)$ & $(0.000)$ \\
- & - & - & - & -0.000 & $-0.002^{* * *}$ & $-0.002^{* * *}$ & - \\
- & - & - & - & $(0.000)$ & $(0.000)$ & $(0.000)$ & - \\
- & - & - & - & $0.008^{* * *}$ & $0.006 * * *$ & $0.006^{* * *}$ & $0.006^{* * *}$ \\
- & - & - & - & $(0.001)$ & $(0.001)$ & $(0.001)$ & $(0.001)$ \\
\hline $6,887,539$ & $6,887,539$ & $6,887,539$ & $6,887,539$ & $6,887,539$ & $6,887,539$ & $6,887,539$ & $6,887,539$ \\
No & No & Yes & No & No & No & Yes & No \\
Yes & Yes & Yes & Yes & Yes & Yes & Yes & Yes \\
No & Firm & Firm & Firm-Year & No & Firm & Firm & Firm-Year
\end{tabular}




\section{Table 4: Financing Constraints and Voluntary Turnover}

This table estimates regressions at the worker level. The dependent variable is binary variable equal to one if the worker moves between period $t$ and $t+1$ to a new firm and does not receive any unemployment benefits, and zero otherwise. Shock (large) is an exchange rate shock. "Large" refers to shocks of larger appreciations, within the $20 \%$ highest appreciation quantile within a year, but also in the $50 \%$ highest appreciation quantile for the whole sample. Constrained is a categorical variable equal to $1,2,3$ (1=best rating, $3=$ worst rating). Short-tenured is a dummy equal to one for workers with 0 to 2 years of tenure, and zero otherwise. Polynomial indicates a polynomial of order 12 of the running variable "risk forecast". Sources: SCB LISA, UC AB, Bolagsverket. ${ }^{* * *} \mathrm{p}<0.01 * * \mathrm{p}<0.05 * \mathrm{p}<0.1$.

\begin{tabular}{lcccc} 
& \multicolumn{4}{c}{ Voluntary Turnover } \\
& $(1)$ & $(2)$ & $(3)$ & $(4)$ \\
\cline { 2 - 5 } Short-tenure & $0.040^{* * *}$ & $0.035^{* * *}$ & $0.035^{* * *}$ & $0.040^{* * *}$ \\
Shock (large) & $(0.001)$ & $(0.001)$ & $(0.001)$ & $(0.001)$ \\
& $-0.005^{* * *}$ & $-0.008^{* * *}$ & $-0.008^{* * *}$ & - \\
Short-tenure X Shock (large) & $(0.001)$ & $(0.001)$ & $(0.001)$ & - \\
& $-0.004^{* * *}$ & $0.008^{* * *}$ & $0.008^{* * *}$ & 0.000 \\
Constrained & $(0.001)$ & $(0.001)$ & $(0.001)$ & $(0.002)$ \\
Short-tenure X Constrained & $0.007^{* * *}$ & $0.001^{* * *}$ & $0.004^{* * *}$ & - \\
& $(0.000)$ & $(0.000)$ & $(0.001)$ & - \\
Shock (large)=1 X Constrained & 0.000 & $-0.001^{* * *}$ & $-0.001^{* * *}$ & $-0.002^{* * *}$ \\
Short-tenure X Shock (large)=1 X & $(0.000)$ & $(0.000)$ & $(0.000)$ & $(0.000)$ \\
Constrained & $0.006^{* * *}$ & $0.008^{* * *}$ & $0.007^{* * *}$ & - \\
& $(0.000)$ & $(0.001)$ & $(0.001)$ & - \\
Observations & $-0.001^{*}$ & $-0.005^{* * *}$ & $-0.005^{* * *}$ & -0.001 \\
Polynomials & $(0.001)$ & $(0.001)$ & $(0.001)$ & $(0.001)$ \\
Industry-Year fixed effects & $6,887,537$ & $6,887,537$ & $6,887,537$ & $6,887,537$ \\
Firm fixed effects & No & No & Yes & No \\
\cline { 2 - 4 } & Yes & Yes & Yes & Yes \\
& No & Firm & Firm & Firm-Year
\end{tabular}


Table 5: Worker Profiles. Short-tenure: Fired vs. Stayers

The dependent variable is the average worker fixed effect of a wage regression including a third order polynomial on age, firm and year fixed effects averaged at a firm level for low tenured workers (0-2 years with the firm) that are fired or stay with the firm. Rating is a categorical variable equal to 1 , 2 or 3 (1=best rating, 3=worst rating). Shock (large) is an exchange rate shock. "Large" refers to shocks of larger appreciations, within the $20 \%$ highest appreciation quantile within a year, but also in the $50 \%$ highest appreciation quantile for the whole sample. Sources: SCB LISA, UC AB, Bolagsverket. *** $\mathrm{p}<0.01 * *$ $\mathrm{p}<0.05 * \mathrm{p}<0.1$.

Shock (large)

Constrained

Shock (large) X Constrained

Observations

Industry-Year fixed effects

Firm fixed effects
Worker wage fixed effect

Fired

\begin{tabular}{cccc}
\multicolumn{2}{c}{ Fired } & \multicolumn{2}{c}{ Stayers } \\
\hline$-0.030^{*}$ & $-0.027^{*}$ & $-0.012^{* *}$ & $-0.015^{* * *}$ \\
$(0.016)$ & $(0.014)$ & $(0.005)$ & $(0.004)$ \\
$-0.011^{* * *}$ & -0.006 & $-0.020^{* * *}$ & $-0.003^{* * *}$ \\
$(0.003)$ & $(0.004)$ & $(0.001)$ & $(0.001)$ \\
$0.016^{* *}$ & $0.016^{* *}$ & $0.010^{* * *}$ & $0.009^{* * *}$ \\
$(0.008)$ & $(0.007)$ & $(0.003)$ & $(0.002)$ \\
\hline
\end{tabular}

$\begin{array}{cccc}5526 & 5526 & 39184 & 39184 \\ \text { Yes } & \text { Yes } & \text { Yes } & \text { Yes } \\ \text { No } & \text { Yes } & \text { No } & \text { Yes }\end{array}$


Table 6: Financing Constraints and Wage Profiles

This table estimates regressions at the worker level. The dependent variable is a binary variable equal to one if the worker leaves the firm in period t and receives unemployment benefits afterwards, and zero otherwise. Specifications (1) to (3) focus on short-tenured workers and (4) to (6) on long-tenured workers. Short-tenured is a dummy equal to one for workers with 0 to 2 years of tenure, and zero otherwise. Long-tenured is a dummy equal to one for workers with more than 2 years of tenure, and zero otherwise. High wage growth takes value one if the worker is above the median predicted wage growth in a regression that uses only unconstrained firms. Shock (large) is an exchange rate shock. "Large" refers to shocks of larger appreciations, within the 20\% highest appreciation quantile within a year, but also in the $50 \%$ highest appreciation quantile for the whole sample. Constrained is a categorical variable equal to 1, 2, 3 . (1=best rating, $3=$ worst rating). Polynomial indicates a polynomial of order 12 of the running variable "risk forecast". Sources: SCB LISA, UC AB, Bolagsverket. *** $\mathrm{p}<0.01 * * \mathrm{p}<0.05 * \mathrm{p}<0.1$.

High wage growth

High wage growth $\mathrm{X}$ Shock (large)

High wage growth $\mathrm{X}$ Constrained

High wage growth $\mathrm{X}$ Shock (large) X Constrained

Shock (large) $=1$

Constrained

Shock (large) X Constrained

Observations

Polynomials

Industry-Year fixed effects

Firm fixed effects

\begin{tabular}{ccc|ccc}
\multicolumn{5}{c}{ Fired Next Year } \\
$(1)$ & Short-tenured & \multicolumn{4}{c}{ Long-tenured } \\
\hline $0.050^{* * *}$ & $0.040^{* * *}$ & $0.038^{* * *}$ & $0.008^{* * *}$ & $0.008^{* * *}$ & $0.008^{* * *}$ \\
$(0.001)$ & $(0.001)$ & $(0.001)$ & $(0.000)$ & $(0.000)$ & $(0.000)$ \\
$-0.030^{* * *}$ & $-0.024^{* * *}$ & $-0.014^{* * *}$ & 0.000 & $-0.002^{*}$ & $-0.002^{* *}$ \\
$(0.002)$ & $(0.002)$ & $(0.002)$ & $(0.001)$ & $(0.001)$ & $(0.001)$ \\
$0.006^{* * *}$ & $0.004^{* * *}$ & $0.004^{* * *}$ & $0.004^{* * *}$ & $0.003^{* * *}$ & $0.003^{* * *}$ \\
$(0.000)$ & $(0.000)$ & $(0.000)$ & $(0.000)$ & $(0.000)$ & $(0.000)$ \\
$0.010^{* * *}$ & $0.009^{* * *}$ & $0.004^{* * *}$ & -0.001 & 0.001 & $0.001^{*}$ \\
$(0.001)$ & $(0.001)$ & $(0.001)$ & $(0.001)$ & $(0.001)$ & $(0.001)$ \\
$-0.004^{* * *}$ & $0.020^{* * *}$ & - & -0.000 & $0.005^{* * *}$ & - \\
$(0.002)$ & $(0.002)$ & - & $(0.001)$ & $(0.001)$ & - \\
$0.004^{* * *}$ & $-0.004^{* * *}$ & - & $-0.002^{* * *}$ & $-0.003^{* * *}$ & - \\
$(0.001)$ & $(0.001)$ & - & $(0.001)$ & $(0.001)$ & - \\
-0.001 & $-0.008^{* * *}$ & - & $0.001 *$ & $-0.002^{* * *}$ & - \\
$(0.001)$ & $(0.001)$ & - & $(0.001)$ & $(0.001)$ & - \\
\hline $3,142,867$ & $3,142,867$ & $3,142,867$ & $3,744,672$ & $3,744,672$ & $3,744,672$ \\
Yes & Yes & No & Yes & Yes & No \\
Yes & Yes & Yes & Yes & Yes & Yes \\
No & Firm & Firm-Year & No & Firm & Firm-Year
\end{tabular}




\section{A.1. RDD specification checks}

\section{Table A1}

This table computes the mean and the median absolute inter-annual deviation of the continuous "risk forecast" variable for firms that are in a window of $+5 \% /-5 \%$ observations of the whole sample around the thresholds that determine the discrete ratings.

Rating boundary Silver-Bronze

Threshold Risk Forecast 0.245 0.745

Risk forecast, annual absolute deviation on a $5 \%$ neighborhood

Mean

0.15

0.43

Median

0.36

0.91

\section{Table A2}

This table computes the transition probabilities across the first three rating categories. Transitions outside or from lower ratings are not included in the computation.

\begin{tabular}{|c|c|c|c|c|}
\hline \multirow{2}{*}{\multicolumn{2}{|c|}{ 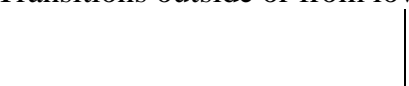 }} & \multicolumn{3}{|c|}{ This year's rating } \\
\hline & & Gold & Silver & Bronze \\
\hline \multirow{3}{*}{ 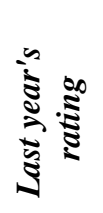 } & Gold & $78 \%$ & $18 \%$ & $4 \%$ \\
\hline & Silver & $28 \%$ & $54 \%$ & $18 \%$ \\
\hline & Bronze & $8 \%$ & $36 \%$ & $56 \%$ \\
\hline
\end{tabular}

Figure A1. Firm Density Around Rating Thresholds

This figure represents the densities of firms around the 1-2 threshold (0.25\% default probability) and the 2-3 threshold (0.75\% default probability). Mass points at rounded numbers correspond to the risk forecasts pre2006 that are reported in rounded numbers. The rounding is symmetric around the discontinuity and, although these firms are likely to identify a small part of the effect, it is useful to keep them for comparability with the other specifications.
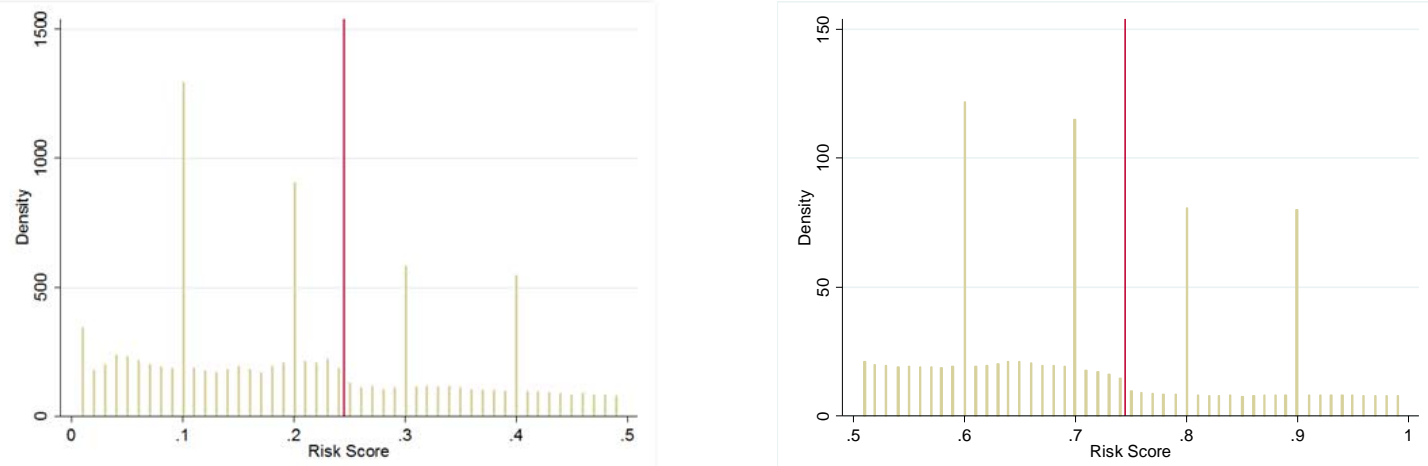


\section{Table A3}

The dependent variable in columns (1)-(3) is the short term banking debt to total assets ratio. The dependent variable in columns (4)-(6) is total banking debt to total assets. The dependent variable in columns (7)-(9) is the interest rate paid to credit institutions. Constrained is a categorical variable equal to $1 \ldots 3$ (1=best rating, 3=worst rating) and is used in (1), (4), and (7). Rating 1 vs. 2 is a dummy that takes the value of one if the rating is 2. It is defined for firms with a rating of 1 or 2 and used in specifications (2), (5), and (8). Rating 2 vs. 3 is a dummy that takes the value of one if the rating is 3. It is defined for firms with a rating of 2 or 3 and used in specifications (3), (6), and (9). Polynomial indicates a polynomial of order 12 of the running variable "risk forecast". All variables are constructed as $\%$. ${ }^{* * *} \mathrm{p}<0.01{ }^{* *} \mathrm{p}<0.05 * \mathrm{p}<0.1$

\section{Panel A: Contemporaneous Ratings}

\begin{tabular}{|c|c|c|c|c|c|c|c|c|c|}
\hline & \multicolumn{3}{|c|}{$\begin{array}{c}\text { Short Term Banking Debt/Total } \\
\text { Assets }\end{array}$} & \multicolumn{3}{|c|}{ Total Banking Debt/Total Assets } & \multicolumn{3}{|c|}{ Interest rate paid to credit institutions } \\
\hline & (1) & $(2)$ & (3) & (4) & (5) & (6) & $(7)$ & (8) & (9) \\
\hline $\begin{array}{l}\text { Constrained } \\
\text { Constrained } \\
1 \text { vs. } 2 \text { \& } 2 \text { vs } 3\end{array}$ & $\begin{array}{c}-0.0292 \\
(0.0409)\end{array}$ & $\begin{array}{l}-0.0116 \\
(0.1000)\end{array}$ & $\begin{array}{c}-0.190 * * * \\
(0.0710)\end{array}$ & $\begin{array}{c}-0.171 \\
(0.110)\end{array}$ & $\begin{array}{l}-0.417 \\
(0.272)\end{array}$ & $\begin{array}{l}-0.200 \\
(0.188)\end{array}$ & $\begin{array}{c}0.156 * \\
(0.0859)\end{array}$ & $\begin{array}{l}0.0819 \\
(0.228)\end{array}$ & $\begin{array}{c}0.298 * * \\
(0.143)\end{array}$ \\
\hline Observations & 108,789 & 58,982 & 84,319 & 176,543 & 91,620 & 140,453 & 177,100 & 89,035 & 142,573 \\
\hline R-squared & 0.728 & 0.782 & 0.747 & 0.757 & 0.809 & 0.772 & 0.616 & 0.687 & 0.643 \\
\hline Year-Sector FE & yes & Yes & yes & yes & yes & yes & yes & yes & yes \\
\hline Firm FE & yes & Yes & yes & yes & yes & yes & yes & yes & yes \\
\hline Polynomial & yes & Yes & yes & yes & yes & yes & yes & yes & yes \\
\hline
\end{tabular}


Panel B: Ratings 1 year after

\begin{tabular}{|c|c|c|c|c|c|c|c|c|c|}
\hline & \multicolumn{3}{|c|}{$\begin{array}{c}\text { Short Term Banking Debt/Total } \\
\text { Assets }\end{array}$} & \multicolumn{3}{|c|}{ Total Banking Debt/Total Assets } & \multicolumn{3}{|c|}{ Interest rate paid to credit institutions } \\
\hline & $(1)$ & $(2)$ & (3) & (4) & (5) & (6) & (7) & (8) & (9) \\
\hline Constrained & $\begin{array}{l}-0.0301 \\
(0.0473)\end{array}$ & & & $\begin{array}{l}-0.0433 \\
(0.127)\end{array}$ & & & $\begin{array}{c}0.0197 \\
(0.0853)\end{array}$ & & \\
\hline $\begin{array}{l}\text { Constrained } \\
1 \text { vs. } 2 \text { \& } 2 \text { vs } 3\end{array}$ & & $\begin{array}{l}0.0108 \\
(0.108)\end{array}$ & $\begin{array}{c}-0.108 \\
(0.0848)\end{array}$ & & $\begin{array}{l}-0.499 * \\
(0.287)\end{array}$ & $\begin{array}{l}-0.0553 \\
(0.220)\end{array}$ & & $\begin{array}{l}-0.0142 \\
(0.215)\end{array}$ & $\begin{array}{c}3.57 \mathrm{e}-05 \\
(0.149)\end{array}$ \\
\hline Observations & 65,966 & 41,251 & 48,284 & 113,080 & 67,632 & 85,815 & 113,004 & 65,235 & 87,300 \\
\hline R-squared & 0.772 & 0.811 & 0.794 & 0.787 & 0.828 & 0.803 & 0.655 & 0.710 & 0.684 \\
\hline Year-Sector FE & yes & Yes & yes & yes & yes & yes & yes & yes & yes \\
\hline Firm FE & yes & Yes & yes & yes & yes & yes & yes & yes & yes \\
\hline Polynomial & yes & Yes & yes & yes & yes & yes & yes & yes & yes \\
\hline
\end{tabular}

Panel C: Ratings 2 years after

\begin{tabular}{|c|c|c|c|c|c|c|c|c|c|}
\hline & \multicolumn{3}{|c|}{$\begin{array}{c}\text { Short Term Banking Debt/Total } \\
\text { Assets }\end{array}$} & \multicolumn{3}{|c|}{ Total Banking Debt/Total Assets } & \multicolumn{3}{|c|}{ Interest rate paid to credit institutions } \\
\hline Constrained & $\begin{array}{c}0.0455 \\
(0.0577)\end{array}$ & & & $\begin{array}{l}0.0108 \\
(0.147)\end{array}$ & & & $\begin{array}{c}0.00422 \\
(0.103)\end{array}$ & & \\
\hline $\begin{array}{l}\text { Constrained } \\
1 \text { vs. } 2 \& 2 \text { vs } 3\end{array}$ & & $\begin{array}{r}-0.0489 \\
(0.121) \\
\end{array}$ & $\begin{array}{l}0.0231 \\
(0.108) \\
\end{array}$ & & $\begin{array}{l}-0.370 \\
(0.310) \\
\end{array}$ & $\begin{array}{c}0.184 \\
(0.270) \\
\end{array}$ & & $\begin{array}{c}0.193 \\
(0.235) \\
\end{array}$ & $\begin{array}{l}-0.186 \\
(0.182) \\
\end{array}$ \\
\hline Observations & 46,518 & 31,234 & 32,418 & 83,115 & 53,054 & 60,785 & 83,678 & 51,675 & 62,400 \\
\hline Year-Sector FE & yes & yes & yes & yes & yes & yes & yes & yes & yes \\
\hline Firm FE & yes & yes & yes & yes & yes & yes & yes & yes & yes \\
\hline Polynomial & yes & yes & yes & yes & yes & yes & yes & yes & yes \\
\hline
\end{tabular}




\section{A.2. Proofs}

\section{Proof of proposition 1}

First, we compute $\mu_{\text {min }}^{O}$. From (Error! Reference source not found.) and (9) we obtain $\left(\frac{A}{n^{1-\beta}} \mu_{\min }^{O}-w\right) \frac{1}{\Delta}+F=0$, where $\Delta \stackrel{\text { def }}{=} \frac{\delta+r+\lambda}{1+r+\lambda}$. Solving we get $\mu_{\min }^{O}=\frac{n^{1-\beta}}{A}[w-\Delta F]$. Substituting in 5 and rearranging: $E\left[V^{O}\left(\mu^{O}\right)\right]=\frac{1}{2}\left(\frac{A}{n^{1-\beta}} \phi \mu^{H}-w\right) \frac{1}{\Delta}-\frac{1}{2} F$.

Therefore an increase in financing frictions $\lambda$ lowers $E\left[V^{O}\left(\mu^{O}\right)\right]$ because it reduces the net present value of worker's surplus (the term $\frac{1}{\Delta}$ becomes smaller). Given the value of $E\left[V^{O}\left(\mu^{O}\right)\right]$, recall the value of a short-term worker (4). An increase in financing fricions $\lambda$ reduces the value of a short tenured worker $V^{Y}\left(\mu^{Y}\right)$ both because it reduces the option value of becoming long-tenured $E\left[V^{O}\left(\mu^{O}\right)\right]$, and because it reduces the net present value of remaining short-tenured (the multiplier in front of the curly brakets also falls).

Therefore the term $E_{t}\left[V^{Y}\left(\mu^{Y}\right)\right]$ falls, and it needs to be counterbalanced by a reduction in $n$ to increase the productivity of workers and reestablish the equilibrium in the free entry condition $E_{t}\left[V^{Y}\left(\mu^{Y}\right)\right]-v=0$.

\section{Proof of proposition 2}

From the firing condition for young workers, $V^{Y}\left(\mu_{\min }^{Y}\right)=0$, we derive $\mu_{\min }^{Y}=$ $\frac{n^{1-\beta}}{A}\left\{w-\frac{(1-\delta)}{1+r+\lambda} \eta E\left[V^{O}\left(\mu^{O}\right)\right]\right\}$. From the discussion above it follows that $\mu_{\min }^{Y}$ increases as $\lambda$ increases. Moreover $\mu_{\min }^{O}$ falls, because $\Delta$ increases.

\section{Proof of proposition 4}

From the definitions of $\mu_{\min }^{O}$ and $\mu_{\min }^{Y}$ derived above it follows that $\frac{\partial \mu_{\min }^{Y}}{\partial A}=-\frac{n^{1-\beta}}{A^{2}}\left\{w-\frac{(1-\delta)}{1+r+\lambda} \eta E\left[V^{O}\left(\mu^{O}\right)\right]\right\}$ and $\frac{\partial \mu_{\min }^{O}}{\partial A}=-\frac{n^{1-\beta}}{A^{2}}[w-\Delta F]$. Given that 
workers are uniformly distributed over productivities, proposition 4 is equivalent to saying that $\frac{\partial \mu_{\min }^{Y}}{\partial A}-\frac{\partial \mu_{\min }^{O}}{\partial A}$ increases in $\lambda$. Therefore the proof follows immediately from the fact that $\left\{w-\frac{(1-\delta)}{1+r+\lambda} \eta E\left[V^{O}\left(\mu^{O}\right)\right]\right\}$ increases in $\lambda$, while $[w-\Delta F]$ decreases in $\lambda$, as argued before. 


\section{External Appendix}

\section{EA.1. Data}

\section{Data Universe:}

Firms: Population of Swedish firms from 1998 until 2010. Source - Swedish Companies Registration Office (Bolagsverket). We standardize all firm data into January to December fiscal years by calculating monthly flow data and aggregating or by averaging stock data. Restricted to firms that: i) employ least 10 workers, ii) appear at least for 5 consecutive years in the data, and iii) with yearly workforce growth within -50\% and $+50 \%$.

Workers: "Longitudinal integration database for health insurance and labor market studies” (LISA). All individuals 16 years of age and older that were registered in Sweden as of December 31 for each year.

Sectors: Data comes from SNI1992 (1990-2001), SNI2002 (2002-2010), and SNI2007 (2011) classification. Consolidated at the SNI2002 level.

Ratings: Source - UC AB. Credit scores range from 1 (least constrained) to 5 (most constrained). Risk Forecast” measures the annual probability of default of the firm. Coverage from 2001 to 2011.

International trade data: Source - Statistics Sweden. Trade type (import/export), product (8-digit classification), and country for each organization between 2000 and 2011.

\section{Variables:}

Tenure: Tenure of a worker with her current firm in years. 
Fraction of workers with tenure 0-2 years: Fraction of workers with tenure below two years calculated at the firm-year level.

Short tenure: Takes value one if a worker has less than two years of tenure within the firm and zero otherwise.

Fired: Takes value one if a worker leaves the firm within the next year and receives unemployment benefits and zero otherwise.

Voluntary turnover: Takes value one if a worker is moving to a different company and does not receive any unemployment benefits in the transition period.

Firm-specific exchange rate: Exchange rate of the Swedish Krona with respect to a weighted basket of the representative currencies of the firm exports in 2000.

Shock (large): Observations within the 20\% highest appreciation of their firm-specific exchange rate quantile within a year, but also in the $50 \%$ highest appreciation quantile for the whole sample in all years. Specifically Shock $\operatorname{Index}_{f, t}=\sum_{c} \omega_{f, c, 0} * e_{-}$change $e_{c, t}$ where $e_{-}$change is the change of exchange rate with currency $c$ over the last year, i.e., $e_{-}$change $e_{c, t}=\ln \left(F X_{c, t}\right)-\ln \left(F X_{c, t-1}\right)$, and $\omega_{f, c, 0}$ are fixed export weights.

Shock (small): Observations within the 20\% highest appreciation of their firm-specific exchange rate quantile within a year.

Specifically, Shock Index $\operatorname{ft}_{f, t}=\sum_{c} \omega_{f, c, 0} * e_{-}$change $e_{c, t}$, where $e_{-}$change is the change of exchange rate with currency $c$ over the last year, i.e., $e_{-}$change $e_{c, t}=\ln \left(F X_{c, t}\right)-\ln \left(F X_{c, t-1}\right)$, and $\omega_{f, c, 0}$ are fixed export weights. 
Constrained: Categorical variable 1=gold rating (best), 2=silver rating and 3=bronze rating (worst rating). Firms with ratings below bronze rating are excluded from the sample.

Constrained 1 vs. 2 (Constrained 2 vs. 3): A dummy variable that is equal to one if the rating is silver and zero if the rating is gold (dummy variable that is equal to one if the rating is bronze and zero if the rating is silver).

High wage growth: A dummy that takes value one if the worker is above the median predicted wage growth in a regression that uses only unconstrained firms with the independent variables age minus six minus years of education (potential experience), gender, number of children, marital status, grades and program in high school and highest level of education.

Worker Wage Fixed Effect: Average worker fixed effect of a wage regression including a third order polynomial on age, firm and year fixed effects averaged at a firm level for low tenured workers (0-2 years with the firm) that are fired or stay with the firm.

\section{EA.2. Robustness Checks}

In the paper, we have pooled the average effect of dropping a rating notch between categories 1, 2 and between 2 and 3. This increases the power to estimate the effects but comes at the cost of not identifying potential heterogeneous effects. In Tables EA1 and EA2, we perform the same regressions as in Table 3, but for the individual boundaries between the gold-silver categories and the silver-bronze categories. In particular, we only include firms with ratings 1 and 2 in Table EA1 and firms with ratings 2 and 3 in Table 
EA2. The results are qualitatively consistent across the two individual categories. They are also consistent with the results in Table 3, showing that our previous results are identified by both boundaries.

In quantitative terms, the effect is slightly stronger for the gold-silver threshold. This may be at odds with the fact that, in terms of interest rates, it is a less important threshold than the silver-bronze threshold. However, the gold category (equivalent to a risk free triple A rating in other rating systems) has more persistence than any of the other categories (see Table A2 in the Appendix), so being downgraded from the gold category may predict further future downgrades. For this reason, crossing the gold-silver boundary may contain more information about the long-term financial health of the firm.

In Table EA3 we replicate the analysis in Table 3, but we redefine the shock variable. The shock variable takes value 1 if the firm is in the highest appreciation quantile within a year and zero otherwise. That is, relative to our previous shock definition, we drop the condition that the shock needs to be large in absolute terms and focus only on relative differences within the year. The main advantage of this variable is that it is evenly distributed across years, so it does not capture any aggregate variation of the exchange rate of the Swedish Krona. The results in Table EA3 are consistent with those in Table 3 with, as expected, slightly smaller point estimates on the Shock coefficients.

In Table EA4 we perform an additional robustness check. We restrict the sample to firms that obtained the highest rating ("gold”) for two years in a row and focus on the boundary between gold and silver ratings. The rationale for this specification is that firms that transition from gold to silver rating for the first time are more likely to be surprised 
to be downgraded to the silver category and, hence, less likely to "manage" their rating results in the short run. The results on this subpopulation are qualitatively similar to our previous results in Table 3. However, they are quantitatively much more sizeable compared to our baseline. For instance, the estimated coefficient on the triple interaction is between two to three times larger and more precisely estimated. In other words, the firms for which a change in the rating is closest to an exogenous unexpected shock are the ones for which the pattern of results is clearer, with larger and more significant coefficients. This lends support to the identification strategies of the paper.

In Table EA5, we replace the definition of firing with stricter definitions of firing. In Columns 1 and 2 we require that workers are unemployed for at least 180 days between jobs to classify as fired. In Columns 3 and 4 we require that workers suffer a drop in income of at least $10 \%$ when changing jobs. The results under these stricter definitions of firing are stronger, relative to the baseline firing probability, than the ones in Table 3.

In Table EA6 we replace the definition of high vs low tenured workers with alternative ones. In columns 1 and 2 we define as short-tenured workers those with tenure below one year and in columns 3 and 4 we define them as those with tenure below three years. In columns 5 to 8 we exclude from the analysis those workers with tenure below one year and define short-tenure workers as 1-2 years of tenure (columns 5 and 6) and 13 years of tenure (columns 7 and 8). The results are qualitatively very consistent across specifications and also consistent with those in sections 6.1 and 6.2.

The possibility of hedging could make that firms are heterogeneously exposed to the exchange rate shock. This could add noise and potentially biases to our regressions. There are some reasons to believe that this is not the case. First, our firms are relatively small 
(median of 27 employees), and unlikely to have access to financial derivatives to hedge their currency exposures. Second, when firms hedge against exchange rate fluctuations, they typically hedge their profits directly. If they hedge their sales, exports or imports, they hedge a notional amount of them. Hedging the actual amount of exports would require a tailor made contract that would be subject to moral hazard considerations. Given this, the operational decisions of a hedged firm ad a non-hedged firms would be the same, as the price paid/received in the margin for inputs and exports is the same for both types of firms. To show that our results are robust to the possibility of hedging, in Table EA7 we run regressions in which we exclude all firms that hold financial assets. Although we do not have more disaggregated data that show explicitly whether a firm holds derivatives, most forms of currency financial hedging should show up in the firm accounts as part of its financial assets. The results are very similar, and marginally larger on those coefficients that involve the shock variable. This effect could come from the absence of hedging, but also from the relatively smaller size of the firms in the restricted sample. 


\section{Table EA1: Financing Constraints and Firing (Thresholds 1 and 2)}

This table estimates regressions at the worker level. The dependent variable is binary variable equal to one if the worker leaves the firm in period $\mathrm{t}$ and receives unemployment benefits afterwards, and zero otherwise. Shock (large) is an exchange rate shock. "Large" refers to shocks of larger appreciations, within the $20 \%$ highest appreciation quantile within a year, but also in the $50 \%$ highest appreciation quantile for the whole sample. Constrained 1 vs. 2 is a dummy that takes the value of one if the rating is 2 . It is defined for firms with a rating of 1 or 2 . Short-tenured is a dummy equal to one for workers with 0 to 2 years of tenure, and zero otherwise. Polynomial indicates a polynomial of order 12 of the running variable "risk forecast”. Sources: SCB LISA, UC AB, Bolagsverket.*** $\mathrm{p}<0.01 * * \mathrm{p}<0.05 * \mathrm{p}<0.1$.

\begin{tabular}{lcccc} 
& \multicolumn{3}{c}{ Fired Next Year } \\
& $(1)$ & $(2)$ & $(3)$ & $(4)$ \\
\cline { 2 - 5 } Short-tenure & $0.070^{* * *}$ & $0.069^{* * *}$ & $0.069^{* * *}$ & $0.074^{* * *}$ \\
& $(0.000)$ & $(0.000)$ & $(0.000)$ & $(0.000)$ \\
Shock (large) & $0.002^{* * *}$ & $0.007^{* * *}$ & $0.007^{* * *}$ & - \\
& $(0.000)$ & $(0.000)$ & $(0.000)$ & - \\
Short-tenure X Shock (large) & $-0.025^{* * *}$ & $-0.020^{* * *}$ & $-0.020^{* * *}$ & $-0.018^{* * *}$ \\
& $(0.001)$ & $(0.001)$ & $(0.001)$ & $(0.001)$ \\
Constrained 1 vs. 2 & $0.009^{* * *}$ & $-0.005^{* * *}$ & $-0.004^{* * *}$ & - \\
& $(0.000)$ & $(0.000)$ & $(0.001)$ & - \\
Short-tenure X Constrained 1 vs. 2 & $0.017^{* * *}$ & $0.014^{* * *}$ & $0.014^{* * *}$ & $0.013^{* * *}$ \\
& $(0.001)$ & $(0.001)$ & $(0.001)$ & $(0.001)$ \\
Shock (large)=1 X Constrained 1 vs. 2 & $-0.005^{* * *}$ & -0.001 & -0.001 & - \\
& $(0.001)$ & $(0.001)$ & $(0.001)$ & - \\
Short-tenure X Shock (large)=1 X Constrained 1 & $0.015^{* * *}$ & $0.013^{* * *}$ & $0.013^{* * *}$ & $0.005^{* * *}$ \\
vs. 2 & & & & \\
& $(0.001)$ & $(0.001)$ & $(0.001)$ & $(0.002)$ \\
\cline { 2 - 5 } Observations & $5,203,427$ & $5,203,427$ & $5,203,427$ & $5,203,427$ \\
Polynomials & No & No & Yes & No \\
Industry-Year fixed effects & Yes & Yes & Yes & Yes \\
Firm fixed effects & No & Firm & Firm & Firm-Year
\end{tabular}




\section{Table EA2: Financing Constraints and Firing (Thresholds 2 and 3)}

This table estimates regressions at the worker level. The dependent variable is binary variable equal to one if the worker leaves the firm in period $t$ and receives unemployment benefits afterwards, and zero otherwise. Shock (large) is an exchange rate shock. "Large" refers to shocks of larger appreciations, within the $20 \%$ highest appreciation quantile within a year, but also in the $50 \%$ highest appreciation quantile for the whole sample. Constrained 2 vs. 3 is a dummy that takes the value of one if the rating is 3 . It is defined for firms with a rating of 2 or 3 . Short-tenured is a dummy equal to one for workers with 0 to 2 years of tenure, and zero otherwise. Polynomial indicates a polynomial of order 12 of the running variable "risk forecast”. Sources: SCB LISA, UC AB, Bolagsverket. *** $\mathrm{p}<0.01 * * \mathrm{p}<0.05 * \mathrm{p}<0.1$.

Short-tenure

Fired Next Year

Shock (large)

Short-tenure X Shock (large)

Constrained 2 vs. 3

Short-tenure X Constrained 2 vs. 3

Shock (large)=1 X Rating 2 vs. 3

Short-tenure X Shock (large)=1 X Constrained 2 vs. 3

\begin{tabular}{cccc}
\multicolumn{4}{c}{ Fired Next Year } \\
$(1)$ & $(2)$ & $(3)$ & $(4)$ \\
\hline $0.087^{* * *}$ & $0.083^{* * *}$ & $0.083^{* * *}$ & $0.087^{* * *}$ \\
$(0.001)$ & $(0.001)$ & $(0.001)$ & $(0.001)$ \\
$-0.004^{* * *}$ & $0.004^{* * *}$ & $0.004^{* * *}$ & - \\
$(0.001)$ & $(0.001)$ & $(0.001)$ & - \\
$-0.010^{* * *}$ & $-0.008^{* * *}$ & $-0.008^{* * *}$ & $-0.012^{* * *}$ \\
$(0.001)$ & $(0.001)$ & $(0.001)$ & $(0.001)$ \\
$0.004^{* * *}$ & $0.002^{* * *}$ & -0.000 & - \\
$(0.000)$ & $(0.000)$ & $(0.001)$ & - \\
$-0.003^{* * *}$ & $-0.004^{* * *}$ & $-0.004^{* * *}$ & $-0.003^{* * *}$ \\
$(0.001)$ & $(0.001)$ & $(0.001)$ & $(0.001)$ \\
$0.007^{* * *}$ & $-0.003^{* * *}$ & $-0.003^{* * *}$ & - \\
$(0.001)$ & $(0.001)$ & $(0.001)$ & - \\
$-0.004 * *$ & 0.003 & 0.003 & $0.006^{* * *}$ \\
& & & \\
$(0.002)$ & $(0.002)$ & $(0.002)$ & $(0.002)$ \\
\hline $3,003,019$ & $3,003,019$ & $3,003,019$ & $3,003,019$ \\
No & No & Yes & No \\
Yes & Yes & Yes & Yes \\
No & Firm & Firm & Firm-Year
\end{tabular}

Observations

Polynomials

Industry-Year fixed effects

Firm fixed effects 


\title{
Table EA3: Financing Constraints and Firing (Small Shock)
}

This table estimates regressions at the worker level. The dependent variable is binary variable equal to one if the worker leaves the firm in period $t$ and receives unemployment benefits afterwards, and zero otherwise. Shock (large) is an exchange rate shock. "Small" refers to shocks of larger appreciations, within the $20 \%$ highest appreciation quantile within a year. Constrained is a categorical variable equal to $1,2,3$ (1=best rating, 3=worst rating). Short-tenured is a dummy equal to one for workers with 0 to 2 years of tenure, and zero otherwise. Polynomial indicates a polynomial of order 12 of the running variable "risk forecast”. Sources: SCB LISA, UC AB, Bolagsverket. *** $\mathrm{p}<0.01 * * \mathrm{p}<0.05 * \mathrm{p}<0.1$.

\author{
Short-tenured \\ Shock (small) \\ Short-tenured X Shock (small) \\ Constrained \\ Short-tenured X Constrained \\ Shock (small) X Constrained \\ Short-tenured X Shock (small) X \\ Constrained \\ Observations \\ Polynomials \\ Industry-Year fixed effects \\ Firm fixed effects
}

\begin{tabular}{cccc}
\multicolumn{4}{c}{ Fired Next Year } \\
$(1)$ & $(2)$ & $(3)$ & $(4)$ \\
\hline $0.066^{* * *}$ & $0.066^{* * *}$ & $0.066^{* * *}$ & $0.072^{* * *}$ \\
$(0.000)$ & $(0.001)$ & $(0.001)$ & $(0.001)$ \\
$0.002^{* * *}$ & $0.010^{* * *}$ & $0.010^{* * *}$ & - \\
$(0.000)$ & $(0.001)$ & $(0.001)$ & - \\
$-0.027^{* * *}$ & $-0.023^{* * *}$ & $-0.022^{* * *}$ & $-0.022^{* * *}$ \\
$(0.001)$ & $(0.001)$ & $(0.001)$ & $(0.001)$ \\
$0.007^{* * *}$ & $-0.002^{* * *}$ & 0.000 & - \\
$(0.000)$ & $(0.000)$ & $(0.001)$ & - \\
$0.007^{* * *}$ & $0.005^{* * *}$ & $0.005^{* * *}$ & $0.005^{* * *}$ \\
$(0.000)$ & $(0.000)$ & $(0.000)$ & $(0.000)$ \\
$-0.001^{* * *}$ & $-0.003^{* * *}$ & $-0.003^{* * *}$ & - \\
$(0.000)$ & $(0.000)$ & $(0.000)$ & - \\
$0.005^{* * *}$ & $0.005^{* * *}$ & $0.005^{* * *}$ & $0.005^{* * *}$ \\
$(0.001)$ & $(0.001)$ & $(0.001)$ & $(0.001)$ \\
\hline 6887539 & $6,887,539$ & $6,887,539$ & $6,887,539$ \\
No & No & Yes & No \\
Yes & Yes & Yes & Yes \\
No & Firm & Firm & Firm-Year
\end{tabular}




\section{Table EA4: Financing Constraints and Firing (Previous Gold Firms)}

This table estimates regressions at the worker level. We restrict the sample to firms that were categorized as gold rating for the previous 2 years. This table estimates regressions at the worker level. The dependent variable is binary variable equal to one if the worker leaves the firm in period t and receives unemployment benefits afterwards, and zero otherwise. Shock (large) is an exchange rate shock. "Large" refers to shocks of larger appreciations, within the $20 \%$ highest appreciation quantile within a year, but also in the $50 \%$ highest appreciation quantile for the whole sample. Constrained 1 vs. 2 is a dummy that takes the value of one if the rating is 2 . It is defined for firms with a rating of 1 or 2 . Short-tenured is a dummy equal to one for workers with 0 to 2 years of tenure, and zero otherwise. Polynomial indicates a polynomial of order 12 of the running variable "risk forecast”. Sources: SCB LISA, UC AB, Bolagsverket. *** $\mathrm{p}<0.01{ }^{* *} \mathrm{p}<0.05$ * $\mathrm{p}<0.1$.

Short-tenure

Shock (large)

Short-tenure X Shock (large)

Constrained 1 vs. 2

Short-tenure X Constrained 1 vs. 2

Shock (large)=1 X Constrained 1 vs. 2

Short-tenure X Shock (large) $=1$ X Constrained 1 vs. 2

\section{Observations}

Polynomials

Industry-Year fixed effects

Firm fixed effects

\begin{tabular}{cccc}
\multicolumn{4}{c}{ Fired Next Year } \\
$(1)$ & $(2)$ & $(3)$ & $(4)$ \\
\hline $0.070^{* * *}$ & $0.069^{* * *}$ & $0.069^{* * *}$ & $0.073^{* * *}$ \\
$(0.001)$ & $(0.001)$ & $(0.001)$ & $(0.001)$ \\
$0.009^{* * *}$ & $0.022^{* * *}$ & $0.023^{* * *}$ & - \\
$(0.001)$ & $(0.002)$ & $(0.002)$ & - \\
$-0.058^{* * *}$ & $-0.046^{* * *}$ & $-0.046^{* * *}$ & $-0.032^{* * *}$ \\
$(0.002)$ & $(0.003)$ & $(0.003)$ & $(0.003)$ \\
$0.006^{* * *}$ & $0.002^{* * *}$ & $0.010^{* * *}$ & - \\
$(0.000)$ & $(0.001)$ & $(0.002)$ & - \\
$-0.002^{* *}$ & -0.000 & -0.001 & $-0.002^{* *}$ \\
$(0.001)$ & $(0.001)$ & $(0.001)$ & $(0.001)$ \\
$-0.007^{* * *}$ & $-0.012^{* * *}$ & $-0.013^{* * *}$ & - \\
$(0.001)$ & $(0.001)$ & $(0.001)$ & - \\
$0.026 * * *$ & $0.026^{* * *}$ & $0.020^{* * *}$ & $0.013^{* * *}$ \\
$(0.002)$ & $(0.002)$ & $(0.002)$ & $(0.002)$ \\
\hline & & & \\
$2,578,093$ & $2,578,093$ & $2,578,093$ & $2,578,093$ \\
No & No & Yes & No \\
Yes & Yes & Yes & Yes \\
No & Firm & Firm & Firm-Year
\end{tabular}




\section{Table EA5: Alternative Specifications of Firing}

This table estimates regressions at the worker level. In columns (1) and (2) the dependent variable is binary variable equal to 1 if the worker leaves the firm in period $t$ and receives unemployment benefits for at least 180 days afterwards, and zero otherwise. In columns (3) and (4) the dependent variable is binary variable equal to one if the worker leaves the firm in period $t$, receives unemployment benefits afterwards and a cut of her disposable income of at least $10 \%$, and zero otherwise. Shock (large) is an exchange rate shock. "Large" refers to shocks of larger appreciations, within the $20 \%$ highest appreciation quantile within a year, but also in the $50 \%$ highest appreciation quantile for the whole sample. Constrained is a categorical variable equal to 1,2,3 (1=best rating, $3=$ worst rating). Short-tenured is a dummy equal to one for workers with 0 to 2 years of tenure, and zero otherwise. Polynomial indicates a polynomial of order 12 of the running variable "risk forecast". Sources: SCB LISA, UC AB, Bolagsverket. *** $\mathrm{p}<0.01 * * \mathrm{p}<0.05 *$ $\mathrm{p}<0.1$.

$$
\text { Days unemployed }>180 \mathrm{~d} \quad \text { Income cut }>10 \%
$$

\begin{tabular}{lcccc} 
& $(1)$ & $(2)$ & $(3)$ & $(4)$ \\
\cline { 2 - 4 } Short-tenure & $0.019^{* * *}$ & $0.021^{* * *}$ & $0.031^{* * *}$ & $0.034^{* * *}$ \\
Shock (large) & $(0.000)$ & $(0.000)$ & $(0.000)$ & $(0.000)$ \\
Short-tenure X Shock (large) & $0.006^{* * *}$ & - & $0.009^{* * *}$ & - \\
& $(0.000)$ & - & $(0.000)$ & - \\
Constrained & $-0.010^{* * *}$ & $-0.008^{* * *}$ & $-0.015^{* * *}$ & $-0.016^{* * *}$ \\
& $(0.001)$ & $(0.001)$ & $(0.001)$ & $(0.001)$ \\
Short-tenure X Constrained & $-0.001^{* * *}$ & - & $-0.001^{* * *}$ & - \\
& $(0.000)$ & - & $(0.000)$ & - \\
Shock (large)=1 X & $0.002^{* * *}$ & $0.002^{* * *}$ & $0.001^{* * *}$ & $0.002^{* * *}$ \\
Constrained & $(0.000)$ & $(0.000)$ & $(0.000)$ & $(0.000)$ \\
& $-0.002^{* * *}$ & - & $-0.003^{* * *}$ & - \\
Short-tenure X Shock & $(0.000)$ & - & $(0.000)$ & - \\
(large)=1 X Constrained & $0.003^{* * *}$ & $0.002^{* * *}$ & $0.005^{* * *}$ & $0.005^{* * *}$ \\
& $(0.000)$ & $(0.000)$ & $(0.001)$ & $(0.001)$ \\
Observations & $6,887,539$ & $6,887,539$ & $6,887,539$ & $6,887,539$ \\
Polynomials & Yes & No & Yes & No \\
Industry-Year fixed effects & Yes & Yes & Yes & Yes \\
Firm fixed effects & Firm & Firm-Year & Firm & Firm-Year
\end{tabular}


Table EA6: Alternative Specifications of Tenure

This table estimates regressions at the worker level. The dependent variable is binary variable equal to 1 if the worker leaves the firm in period t and receives unemployment benefits afterwards, and zero otherwise. Shock (large) is an exchange rate shock. "Large" refers to shocks of larger appreciations, within the 20\% highest appreciation quantile within a year, but also in the $50 \%$ highest appreciation quantile for the whole sample. Constrained is a categorical variable equal to 1,2,3 (1=best rating, $3=$ =worst rating). In columns (1) and (2) Short-tenured is a dummy equal to one for workers with 0 to 1 years of tenure, and zero otherwise (Short-tenured is 0 to 3 years in columns (3) and (4), 1 to 2 years in columns (5) and (6), and 1 to 3 years in columns (7) and (8)). We drop all workers with less than 2 years of tenure in specifications (5) to (8). Polynomial indicates a polynomial of order 12 of the running variable "risk forecast”. Sources: SCB LISA, UC AB, Bolagsverket. *** $\mathrm{p}<0.01 * * \mathrm{p}<0.05 * \mathrm{p}<0.1$.

Short-tenure

Shock (large)

Short-tenure X Shock (large)

Constrained

Short-tenure X Constrained

Shock (large)=1 X Constrained

Short-tenure X Shock (large)=1 X Constrained

Observations

Exclude workers with tenure 0-1

Polynomials

Industry-Year fixed effects

Firm fixed effects

\begin{tabular}{|c|c|c|c|c|c|c|c|}
\hline \multirow{2}{*}{\multicolumn{2}{|c|}{ Short-tenure (0-1 years) }} & \multicolumn{4}{|c|}{ Fired Next Year } & \multirow{2}{*}{\multicolumn{2}{|c|}{ Short-tenure (1-3 years) }} \\
\hline & & \multicolumn{2}{|c|}{ Short-tenure (0-3 years) } & \multicolumn{2}{|c|}{ Short-tenure (1-2 years) } & & \\
\hline$(1)$ & $(2)$ & (3) & (4) & (5) & (6) & $(7)$ & $(8)$ \\
\hline $0.077 * * *$ & $0.083^{* * *}$ & $0.057 * * *$ & $0.062 * * *$ & $0.018^{* * *}$ & $0.023 * * *$ & $0.018 * * *$ & $0.021 * * *$ \\
\hline$(0.001)$ & $(0.001)$ & $(0.000)$ & $(0.000)$ & $(0.001)$ & $(0.001)$ & $(0.000)$ & $(0.001)$ \\
\hline $0.010 * * *$ & - & $0.013^{* * *}$ & - & $0.004^{* * *}$ & - & $0.006 * * *$ & - \\
\hline$(0.001)$ & - & $(0.001)$ & - & $(0.001)$ & - & $(0.001)$ & - \\
\hline$-0.027 * * *$ & $-0.026 * * *$ & $-0.017 * * *$ & $-0.020 * * *$ & $-0.009 * * *$ & $-0.012 * * *$ & $-0.005^{* * *}$ & $-0.009 * * *$ \\
\hline$(0.001)$ & $(0.002)$ & $(0.001)$ & $(0.001)$ & $(0.001)$ & $(0.002)$ & $(0.001)$ & $(0.001)$ \\
\hline-0.001 & - & $-0.002 * * *$ & - & $-0.001^{*}$ & - & $-0.001 * *$ & - \\
\hline$(0.001)$ & - & $(0.001)$ & - & $(0.001)$ & - & $(0.001)$ & - \\
\hline $0.005^{* * *}$ & $0.005^{* * *}$ & $0.005^{* * *}$ & $0.005^{* * *}$ & $0.003 * * *$ & $0.003 * * *$ & $0.002 * * *$ & $0.003 * * *$ \\
\hline$(0.000)$ & $(0.000)$ & $(0.000)$ & $(0.000)$ & $(0.000)$ & $(0.000)$ & $(0.000)$ & $(0.000)$ \\
\hline$-0.003 * * *$ & - & $-0.003 * * *$ & - & $-0.001 * * *$ & - & $-0.002 * * *$ & - \\
\hline$(0.000)$ & - & $(0.000)$ & - & $(0.000)$ & - & $(0.000)$ & - \\
\hline $0.007 * * *$ & $0.008^{* * *}$ & $0.004^{* * *}$ & $0.005^{* * *}$ & $0.003^{* * *}$ & $0.003^{* * *}$ & $0.001 *$ & $0.002 * *$ \\
\hline$(0.001)$ & $(0.001)$ & $(0.001)$ & $(0.001)$ & $(0.001)$ & $(0.001)$ & $(0.001)$ & $(0.001)$ \\
\hline $6,887,539$ & $6,887,539$ & $6,887,539$ & $6,887,539$ & $4,599,302$ & 4,599,302 & 4,599,302 & 4,599,302 \\
\hline No & No & No & No & Yes & Yes & Yes & Yes \\
\hline Yes & No & Yes & No & Yes & No & Yes & No \\
\hline Yes & Yes & Yes & Yes & Yes & Yes & Yes & Yes \\
\hline Firm & Firm-Year & Firm & Firm-Year & Firm & Firm-Year & Firm & Firm-Year \\
\hline
\end{tabular}




\section{Table EA7: Exclusion of Firms with Financial Assets}

This table estimates regressions at the worker level. The dependent variable is binary variable equal to one if the worker leaves the firm in period $t$ and receives unemployment benefits afterwards, and zero otherwise. We exclude workers from the sample who work for firms that have financial assets on their balance sheets. Shock (large) is an exchange rate shock. "Large" refers to shocks of larger appreciations, within the $20 \%$ highest appreciation quantile within a year, but also in the $50 \%$ highest appreciation quantile for the whole sample. Constrained is a categorical variable equal to 1,2,3 (1=best rating, $3=$ worst rating). Short-tenured is a dummy equal to one for workers with 0 to 2 years of tenure, and zero otherwise. Polynomial indicates a polynomial of order 12 of the running variable "risk forecast”. Sources: SCB LISA, UC AB, Bolagsverket. *** $\mathrm{p}<0.01 * * \mathrm{p}<0.05 * \mathrm{p}<0.1$.

\section{Fired Next Year}

\begin{tabular}{|c|c|c|}
\hline & $(1)$ & $(2)$ \\
\hline \multirow[t]{2}{*}{ Short-tenure } & $0.067 * * *$ & $0.071^{* * *}$ \\
\hline & $(0.001)$ & $(0.001)$ \\
\hline \multirow[t]{2}{*}{ Shock (large) } & $0.012^{* * *}$ & - \\
\hline & $(0.001)$ & - \\
\hline \multirow[t]{2}{*}{ Short-tenure X Shock (large) } & $-0.024 * * *$ & $-0.031 * * *$ \\
\hline & $(0.001)$ & $(0.001)$ \\
\hline \multirow[t]{2}{*}{ Constrained } & $-0.004 * * *$ & - \\
\hline & $(0.001)$ & - \\
\hline \multirow[t]{2}{*}{ Short-tenure X Constrained } & $0.005^{* * *}$ & $0.005^{* * *}$ \\
\hline & $(0.000)$ & $(0.000)$ \\
\hline \multirow[t]{2}{*}{ Shock (large)=1 X Constrained } & $-0.003 * * *$ & - \\
\hline & $(0.000)$ & - \\
\hline \multirow[t]{2}{*}{ Short-tenure X Shock (large)=1 X Constrained } & $0.007 * * *$ & $0.008 * * *$ \\
\hline & $(0.001)$ & $(0.001)$ \\
\hline Observations & $5,742,486$ & $5,742,486$ \\
\hline Polynomials & Yes & No \\
\hline Industry-Year fixed effects & Yes & Yes \\
\hline Firm fixed effects & Firm & Firm-Year \\
\hline
\end{tabular}




\section{EA.3. Impact of UC Ratings on Interest Rates paid}

It is useful to quantify the impact of changes in UC ratings on the interest rate paid by firms to put in perspective the size of the employment results. There are several useful measurements that help measuring or bounding the effect.

The first approach to measure the marginal change in interest rates is directly from the Panel A of Table A3. In columns (7), (8) and (9) we report the change in the average interest rate paid when firms experience a contemporaneous change in rating. The change is measured at the boundary of a rating change by introducing a polynomial of order 12 on the running variable. The results show an average change of $0.156 \%$ (15 basis points) for both boundaries $0.082 \%$ for the gold to silver boundary (not statistically significant) and $0.299 \%$ for the silver to bronze boundary. These are changes on the average interest rates after an unexpected (marginal) change in rating. Given that firms may have some long-term debt, the effect on the marginal interest rate should be higher.

Alternatively, one can recourse to a risk neutral valuation to measure, or place some bounds, on the effect of ratings on interest rates. Consider the following expression in which a bond of a given rating $c$ has an expected return $\mathrm{R}_{\mathrm{e}}$ :

$$
\left(1+r_{c}\right)\left(1-p_{c}\right)+\left(1+r_{c}\right) p_{c} R_{c}=R_{e}
$$

Where $r_{c}$ is the promised rate on the debt, $p_{c t}$ is the default probability and $R_{c}$ is the recovery rate in case of default. To populate this expression, we can use as default probabilities, the average default probability in each interval $(0.12 \%$ for gold, $0.47 \%$ for silver, and 1.59 for bronze), as recovery rate 35\% (see Thorburn, 2000) and an expected return of $6 \%$. This yields promised rates of $6.08 \%$ for gold, $6.32 \%$ for silver and $7.11 \%$ for bronze. That is, a yield differential of 24 basis points for the gold-silver transition and 78 basis points for the silver-bronze boundary. If we assume a zero recovery rate, the differential grows to 37 basis points and 121 basis points respectively. 